University of Louisville

ThinkIR: The University of Louisville's Institutional Repository

Electronic Theses and Dissertations

$1-1930$

\title{
The fate of water lost from the blood in cocaine fever and the relation of this water to the febrile process.
}

Hubert T. Marshall

University of Louisville

Follow this and additional works at: https://ir.library.louisville.edu/etd

\section{Recommended Citation}

Marshall, Hubert T., "The fate of water lost from the blood in cocaine fever and the relation of this water to the febrile process." (1930). Electronic Theses and Dissertations. Paper 907.

https://doi.org/10.18297/etd/907

This Master's Thesis is brought to you for free and open access by ThinkIR: The University of Louisville's Institutional Repository. It has been accepted for inclusion in Electronic Theses and Dissertations by an authorized administrator of ThinkIR: The University of Louisville's Institutional Repository. This title appears here courtesy of the author, who has retained all other copyrights. For more information, please contact thinkir@louisville.edu. 


\title{
UNIVERSITY OF LOUISVILLE
}

\author{
THT FATE OF WATER LOST FROH THE BLOOD IN COCAINE \\ FEVER AND THE RELATION OF THIS WATER TO THE

\section{FEBRILE PROCESS.}

\author{
A Dissertation \\ Submittea to the Faculty \\ Of the Graduate School of the University of Louisville \\ In Partial Fulfillment of the \\ Requirements for the Degree \\ Of Haster of Science
}

Department of Fhysiology

By

Hubert T. Marshall

1930 
Introduction $\ldots \ldots \ldots \ldots \ldots \ldots \ldots \ldots \ldots \ldots \ldots \ldots \ldots \ldots \ldots \ldots$

I. Investigations concerning a Possible Water Shift Within the Body.

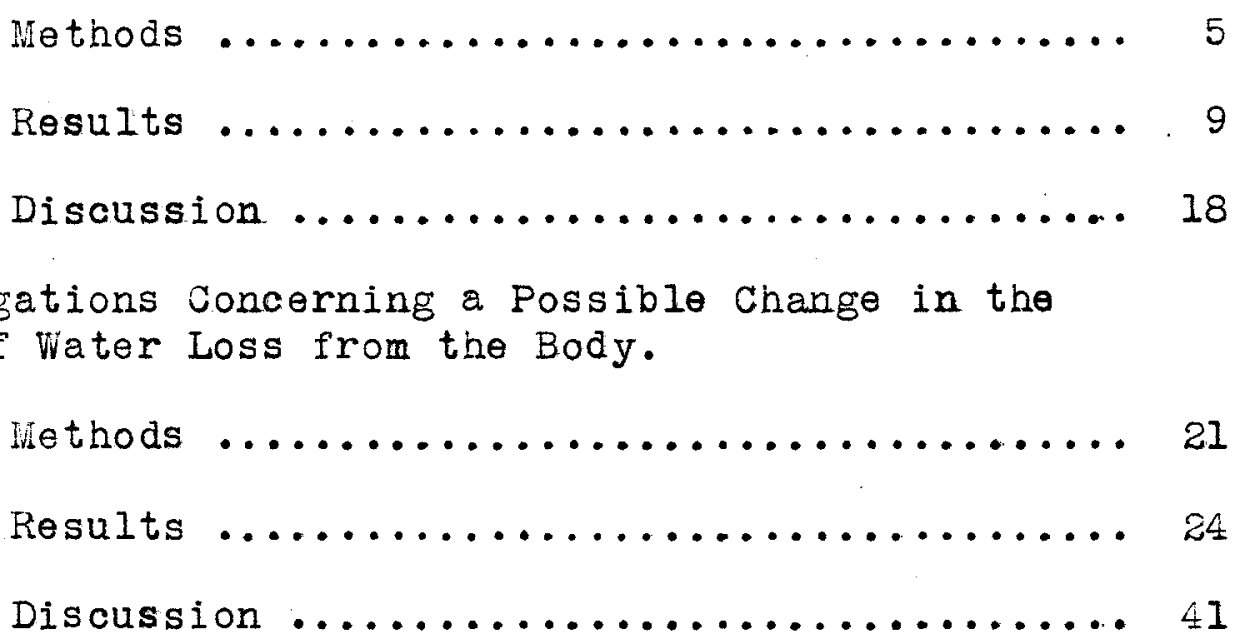

II. Investigations Concerning a Possible Change in the Rate of Water Loss from the Body.

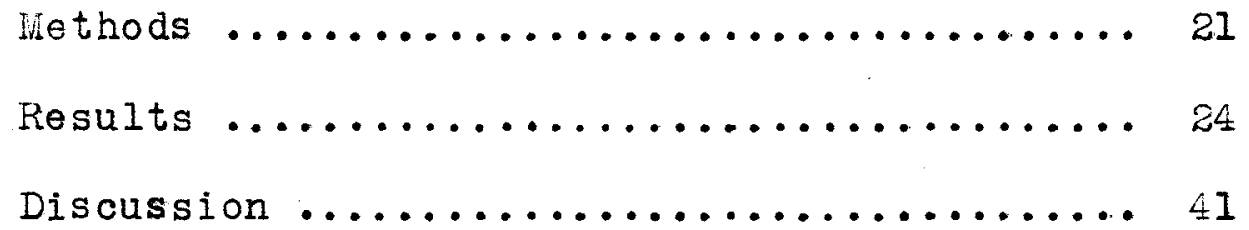

General Significance of Results .................. 44

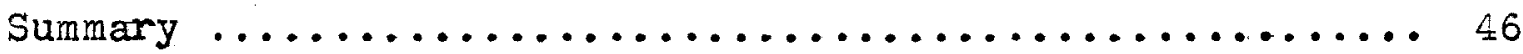

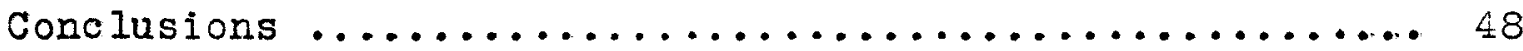

Bibliography .............................. 49 
1

IN TRODUCTION. 
INTRODU C T I ON.

This investigation was carried out in an attempt to determine the nature of some of the physiological changes, particularly the shift in the water balance during the rise in temperature following pyretic doses of cocaine. It is: well known that cocaine in sufficiently large doses produces an almost immediate and rapid rise in body temperature associated with increased metabolism and motor activity. Reichert (1). The increased motor activity becomes evident soon after the injection of the cocaine. Extreme restlessness, muscle twitching and tremor progressing into clonic convulsions may be observed.

Barbour and Moise (2) have shown in dogs given pyretic doses of cocaine that the percentage of blood solids and red blood cells hoth increase coincidentally with the rise in temperature. Later Barbour (3) has shown more conclusively that during the rise in temperature following cocaine in dogs there is a loss of fluid from the blood stream as the specific gravity of bath whole hlood and plasma is inereased. Barbour and Hoise (2) state that the disturbance thus produced in the heat eliminating mechanism of the organism by the concentrated blood is of greater significance for the production of fever than the muscular activity. (Otherwise ordinary exercise would produce high fever.) 
What then is the fate of this fluid which leaves the blood stream? The nater content of the brain was first investigated in an attempt to answer this question because several previous findings indicate a close association between brain edema and pathologically increased muscular activity.

For example, Barbour and others (4) and Flowers, Dunham and Barbour (5) in experiments on acute uthdrawal from morphine addictions in dogs and rats have found an edema of brain, liver and kidneys, anthydremila, diarrbea and a disturbed temperature regulation associated with evidence of increased motor activity shown by restlessness, marked museuler twitching and tremors. Ellerbrook, Dunham and Barbour (6) have described an edema of the brain in rabbits associated with manifestations of increased motor activity following administration of pitressin. McQuarrie (7) has found that parenteral administration of solution of pituitary or of the antidiuretic hormone of hypophysis causes the development of a positive water balence and the occurrence of seizures in the epileptic subject. Rowntree (8) has shown that the injection of large quantities of water subsequent to pituitary extract results regularly in the following tratin af symptoms: Asthenia, restlessness, vamiting, tremor, salitation, muscle twitching, ataxia, clonic and tonic convulsions, frothing at tho mouth and stupor or coms. He has also auceeeded in producing the above train of symptoms by simple 
water intoxication without pituitary extract, In cats with acute parathyroprivia and guanidine tetanfes, Ellis (9) has found that brain, kidney and striated muscle have higher water content than the same tissues from normal control animals. He also finds that the blood in rats in acute: guanidine tetany has a lower water content than normal rat blood.

In the experiments on acute morphine witharawal, pitressin, water intoxication and the parathyroprtiva and guanidine tetanies the symptoms of increased motor excitability, which in most of these was associated with an edema of some body tissues, especially the brain, are closely analagous to those seen following pyretic doses of cocaine. This and other similarities between fever and the conditions just described, lead to the belief that the fluid which leaves the blood stream in cocaine hyperpyrexia might be shifted to the brain and thus account for the similarity of symptoms. The fact that the change in blood concentration following pyretic doses of cocaine is revergible, Barbour and hise, (2) also makes one believe that the fluid remeins somewhere within the body.

Later it was decided to determine more completely the fate of this water which is lost from the blood stream during the rise in temperature. 
The possible sources of deposition or elimination of this water were then studied. The following schema illustrates the method of attack.

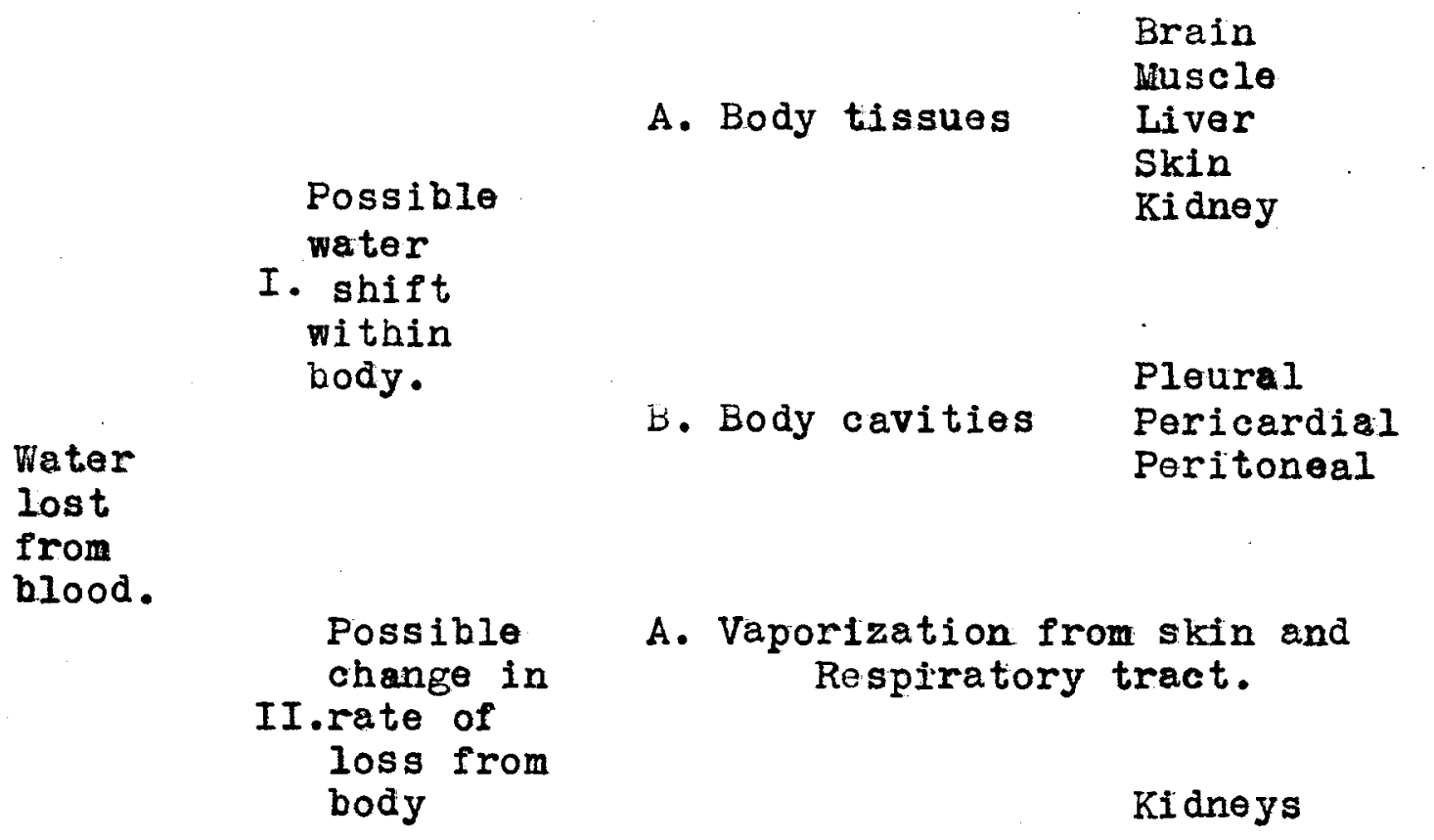

B. Excreted

Saliva

Alimentary tract. Gastrointestinal contents. 

BODY.

3

$\checkmark$ 
I. Investigations Cancerning a Possible Water Shift Within the Body.

\section{METHODS.}

In the experiments healthy adult "New Zealand Red" Rabbits of the same stock were used. Practically all rabits were males, especial care being taken when females wer used to avoid pregnant ones. They were all kept in the same animal room on a standard diet with freo access to water. Only rabits in a good state of nutrition, free from any evidence of disease were used in the experiments.

A few experiments were done to determine the typical effect,for this group of animals, of a standard pyretic dose of cocaine upon the motor activity, rectal temperature and blood specific gravity of rabbits kept, as nearly as possible, under the same conditions as those to be used later in this work. All rectal temperature readings were taken with a clinical thermometer inserted to a standard depth of approximately 8 centimeters, care being taken to get, the maximum reading each time. Specific gravity determinations were made by the falling drop method (10). After some study of the effects of varied doses upon motor activity, rectal temperature and blood specific gravity, standard dose of 40 milligrems per kilo was adopted. The typical effect of this dose upon rabbits kept under our standard conditions is shown 
Table 1.

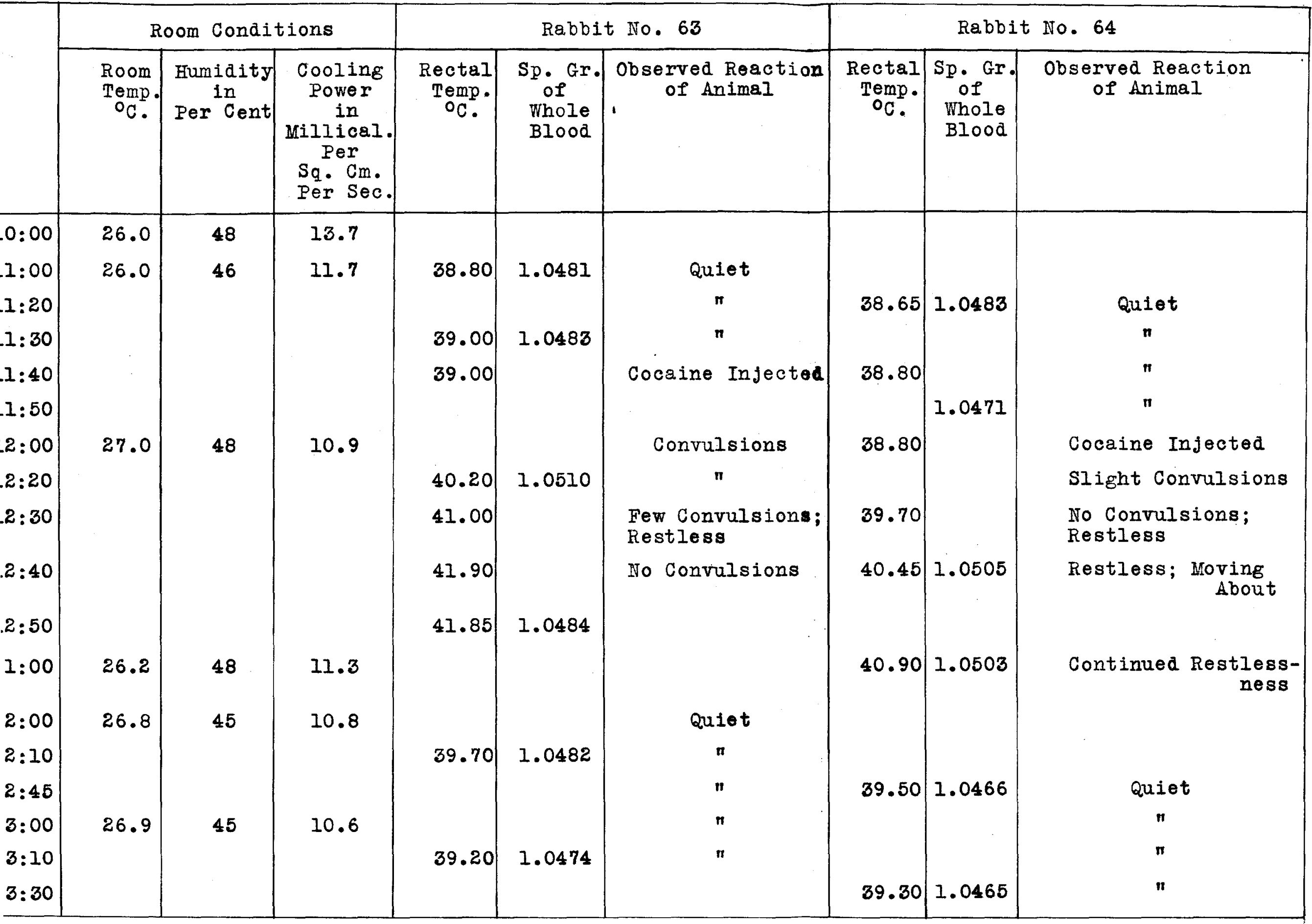


Fig. 1

A. Rabbit No. 64

B. Rabbit No. 63

Showing the effect of cocaine ( 40 mgm. per kilo) on the rectal temperature and blood specifio gravity.

Small dots - reotal temperature.

Large dots - specific gravity of whole blood.

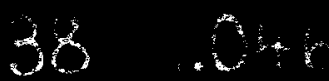




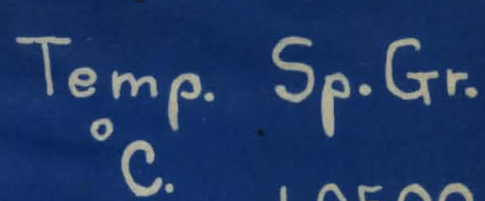
$\begin{array}{ll}{ }^{C} \mathrm{C} . & 1.0500 \\ 48 & 1.0480 \\ 38 & 1.0460\end{array}$

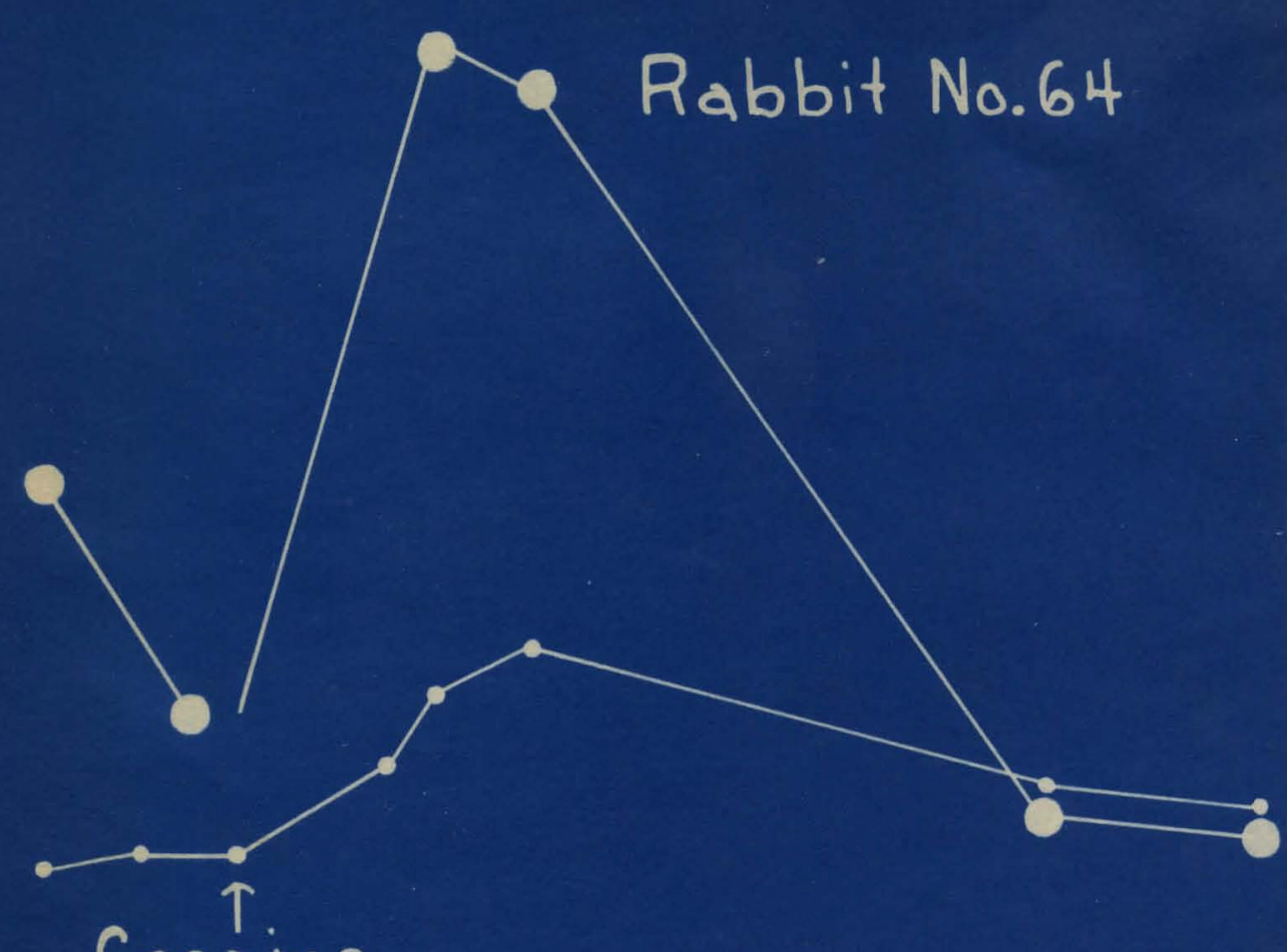

Cocaine

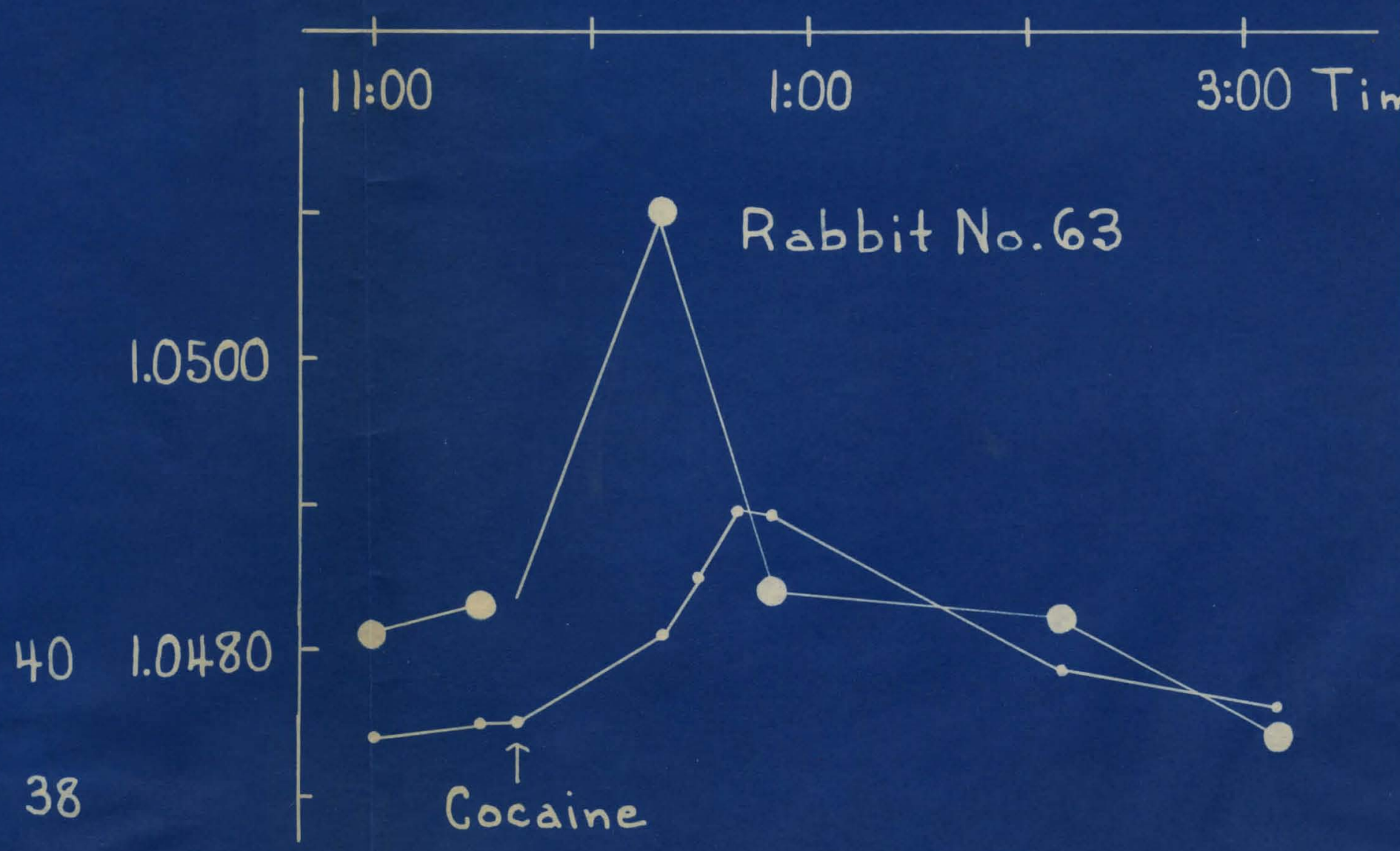


in table $I$. Figures $I A$ and $B$ are plotted from this table. If the fluid hich leaves the blood stream following pyretic doses of cocaine remains within the body it must be shifted to some one or more of the body organs, tissues or cavities. This shift should, therefore, be detected by comparing the percent solids of the body tissues and organs and the fluid content of the body cavities of normal rabbits with those of rabbits fevered with cocaine.

\section{A. Body Tissues.}

During the course of an experiment all animals used were kept under identical conditions and handled similarly. Care was taken to avoid excitement of the animals during the experiment as this is known to cause a marked concentration of the blood (11). If an animal became excited it was either discarded or given ample time to recover completely before it was used.

Koch and Koch (12) have shown that there is a rapid increase in the percent solids of the brain of rats with increasing age up to 120 days. Haldi, Larkin and Wright have shown that the percent solids of the brain of rabbits alao increase slightly with increased age. Therefore, in this work it was deemed necessary to use animals of the same age. Reference to tables 2,3 and 4 will show how well this 
factor was controlled.

To determine the percent solids the animals were quickly decapitated without causing them to become excited and semples of the tissues removed and weighed immediately. Rigid routine during this procedure was maintalned in the entire series so as to eliminate as nearly as possible variability in time from killing to removal and weighing. The tissues were then aried in an oven at 100 to $105^{\circ} \mathrm{C}$. After their weight had become constant the percentage solids was calculated.

\section{RESULTS.}

The results of this series of experiments are tabulated according to groups of rabbits in tables $2 A$ and $B$, 3 and $4 A$ and $B$. Table 5 is a summary of the entire series. Reference to the tables will show that variations due to a slight difference in age between groups is insigniflcant and that the other conditions are well enough controlled to make the entire series comparable. Therefore, it seems justifiable to compare the entire series rather than each group separately. In table five, the column of averege differences between duplicate samples serves as a check on the technical method. The last column showing the standard deviation of 
Table 2 .

A. Average Room Temperature $24.8^{\circ} \mathrm{C}$; Maximum Variation from Average $1.2^{\circ} \mathrm{C}$.

Rabbits 98 Days of Age. Food and Water Removed 4 Hours bofore Experiment.

B. Average Room Temperature $24.25^{\circ} \mathrm{C}$; Maximum Variation from Average $0.25^{\circ} \mathrm{C}$. Rabbits 87 Days of Age. Food and Water Removed 2 Hours bofore Experiment.

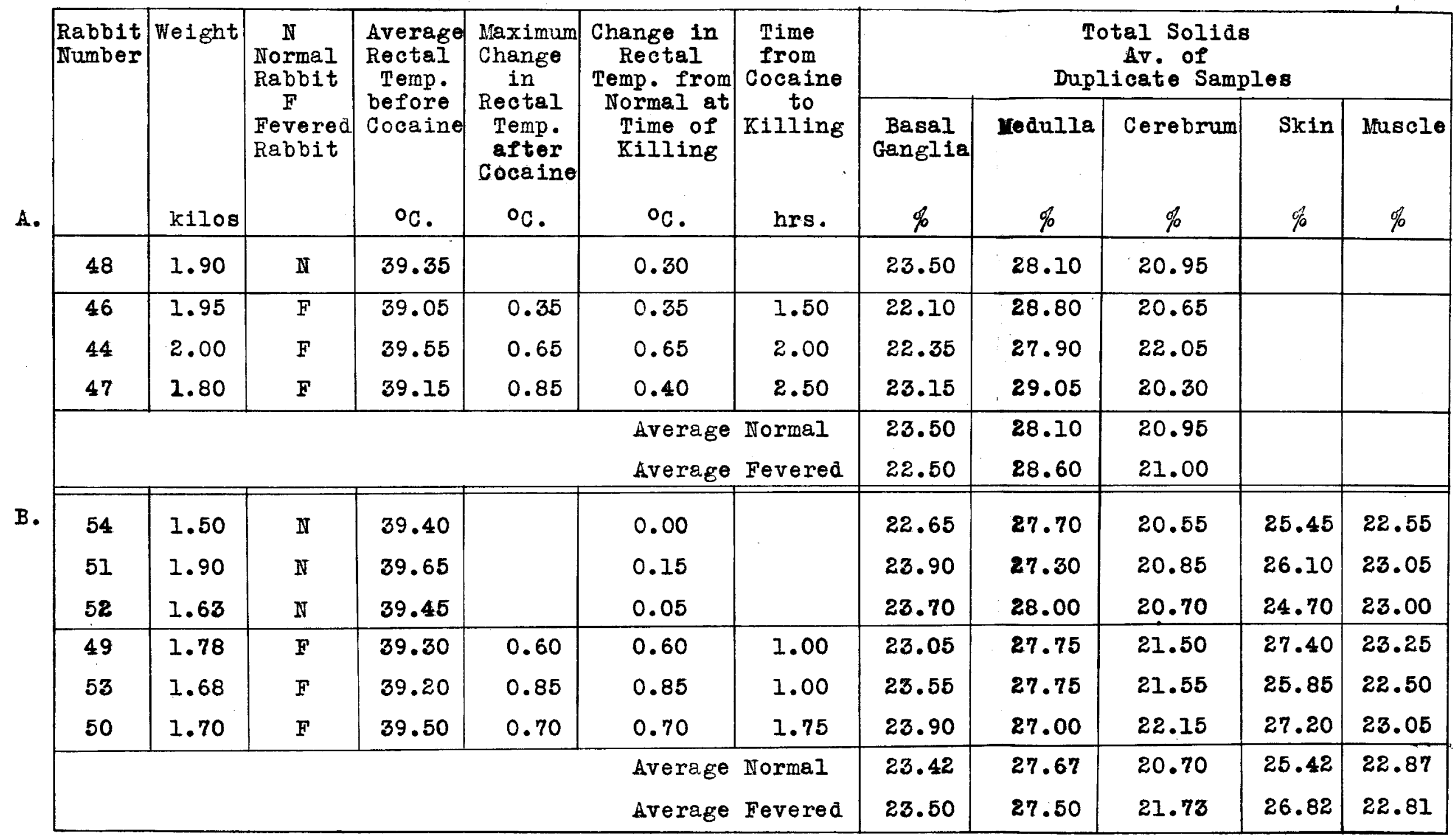


Table 3.

Constant Room Temperature $25^{\circ} \mathrm{C}$.

Food and Water Removed 3 Hou

\begin{tabular}{|c|c|c|c|c|c|c|c|}
\hline $\begin{array}{l}\text { Rabb1t } \\
\text { Number }\end{array}$ & $\begin{array}{l}\text { Weight } \\
\text { kilos }\end{array}$ & $\begin{array}{l}\text { N } \\
\text { Normal } \\
\text { Rabbit } \\
\quad \text { F } \\
\text { Fevered } \\
\text { Rabbit }\end{array}$ & $\begin{array}{l}\text { Average } \\
\text { Rectal } \\
\text { Temp. } \\
\text { before } \\
\text { Cocaine }\end{array}$ & $\begin{array}{l}\text { Maximum } \\
\text { Change } \\
\text { In } \\
\text { Reotal } \\
\text { Temp. } \\
\text { after } \\
\text { Cocaine } \\
{ }^{\circ} \mathrm{C} .\end{array}$ & $\begin{array}{l}\text { Change in } \\
\text { Rectal } \\
\text { Temp. from } \\
\text { Tormal at } \\
\text { Time of } \\
\text { Killing }\end{array}$ & $\begin{array}{l}\text { Time } \\
\text { Irom } \\
\text { Cocaine } \\
\text { to } \\
\text { Kiling }\end{array}$ & $\begin{array}{r}\text { Basa] } \\
\text { Gangl1 } \\
\%\end{array}$ \\
\hline 57 & 2.10 & $\mathbb{N}$ & 39.20 & & 0.00 & & 23.18 \\
\hline 59 & 2.03 & $\mathbf{N}$ & 39.35 & & 0.10 & & 24.25 \\
\hline 68 & 1.88 & $\mathbb{N}$ & 38.90 & & 0.00 & & 23.40 \\
\hline 69 & 1.75 & $N$ & 39.35 & & 0.00 & & 23.40 \\
\hline 65 & 2.34 & $F$ & 39.55 & 1.10 & 1.10 & 0.33 & 23.90 \\
\hline 70 & 1.65 & $F$ & 39.45 & 1.55 & 1.55 & 0.50 & 28.00 \\
\hline 58 & 2.24 & $F$ & 40.00 & 1.10 & 1.10 & 1.00 & 23.41 \\
\hline 60 & 2.00 & $F$ & 39.00 & 1.35 & 1.35 & 1.00 & 23.21 \\
\hline 67 & 1.85 & $F$ & 38.80 & 1.30 & 1.30 & 1.00 & 23.91 \\
\hline \multicolumn{7}{|c|}{ Average Normal } & 23.5 \\
\hline \multicolumn{7}{|c|}{ Average Fevered } & 23.5 \\
\hline
\end{tabular}


Table 3.

ture $25^{\circ} \mathrm{C}$. Rabbits 114 to 121 Days of Age. Removed 3 Hours before Experiment.

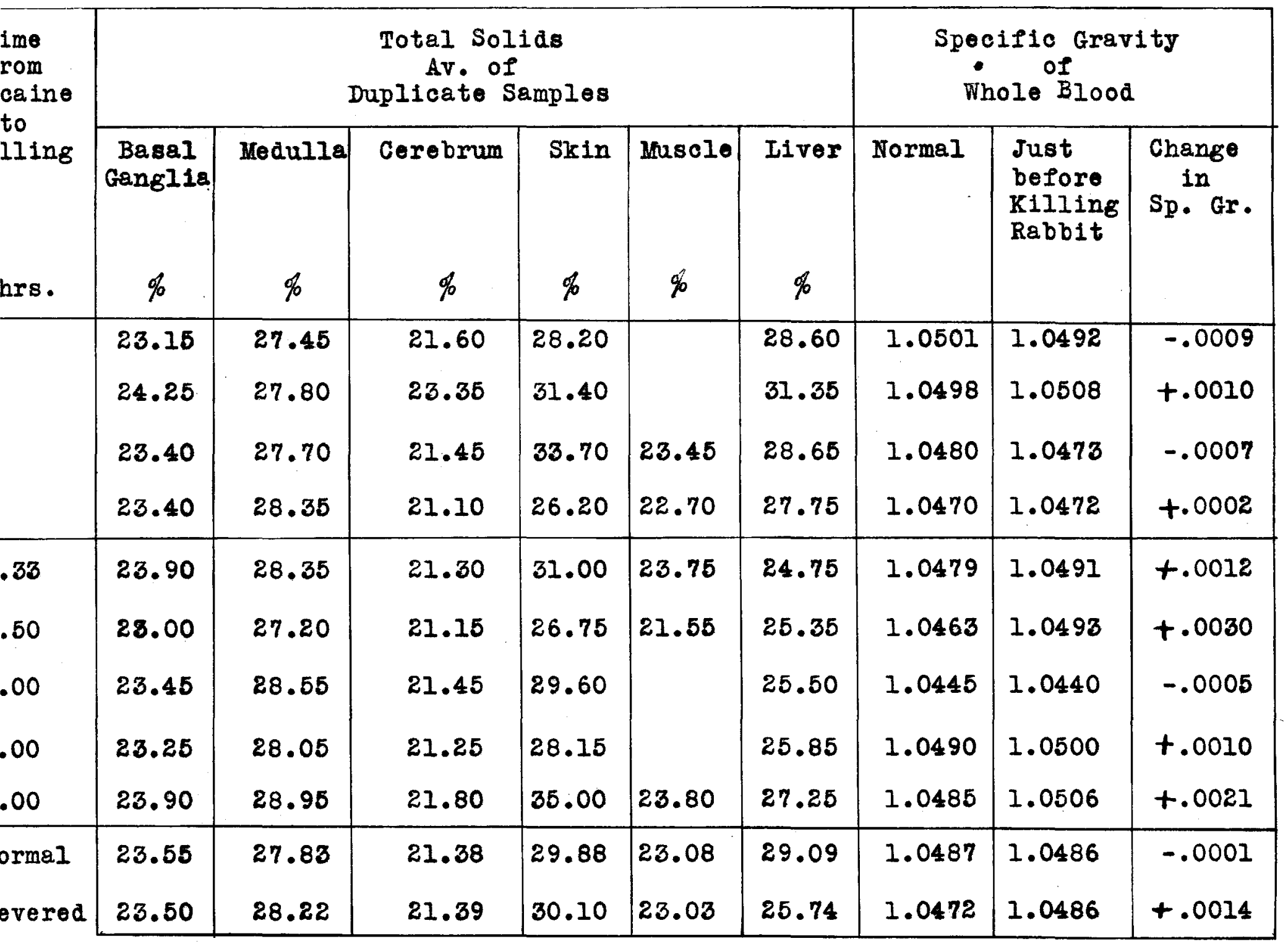


Table 4

A. Average Room Temperature $25.5^{\circ} \mathrm{C} . ;$ Maximum Variation from Average $1.3^{\circ} \mathrm{C}$.

Rabbits 106 to 113 Days of Age. Food and Water Removed 6 Hours before Experiment.

B. Average Room Temperature $29.00^{\circ} \mathrm{C}$; Maximum Variation from Average $1.5^{\circ} \mathrm{C}$. Rabbits 180 Days of Age. Food and Water Removed 5 Hours before Experiment.

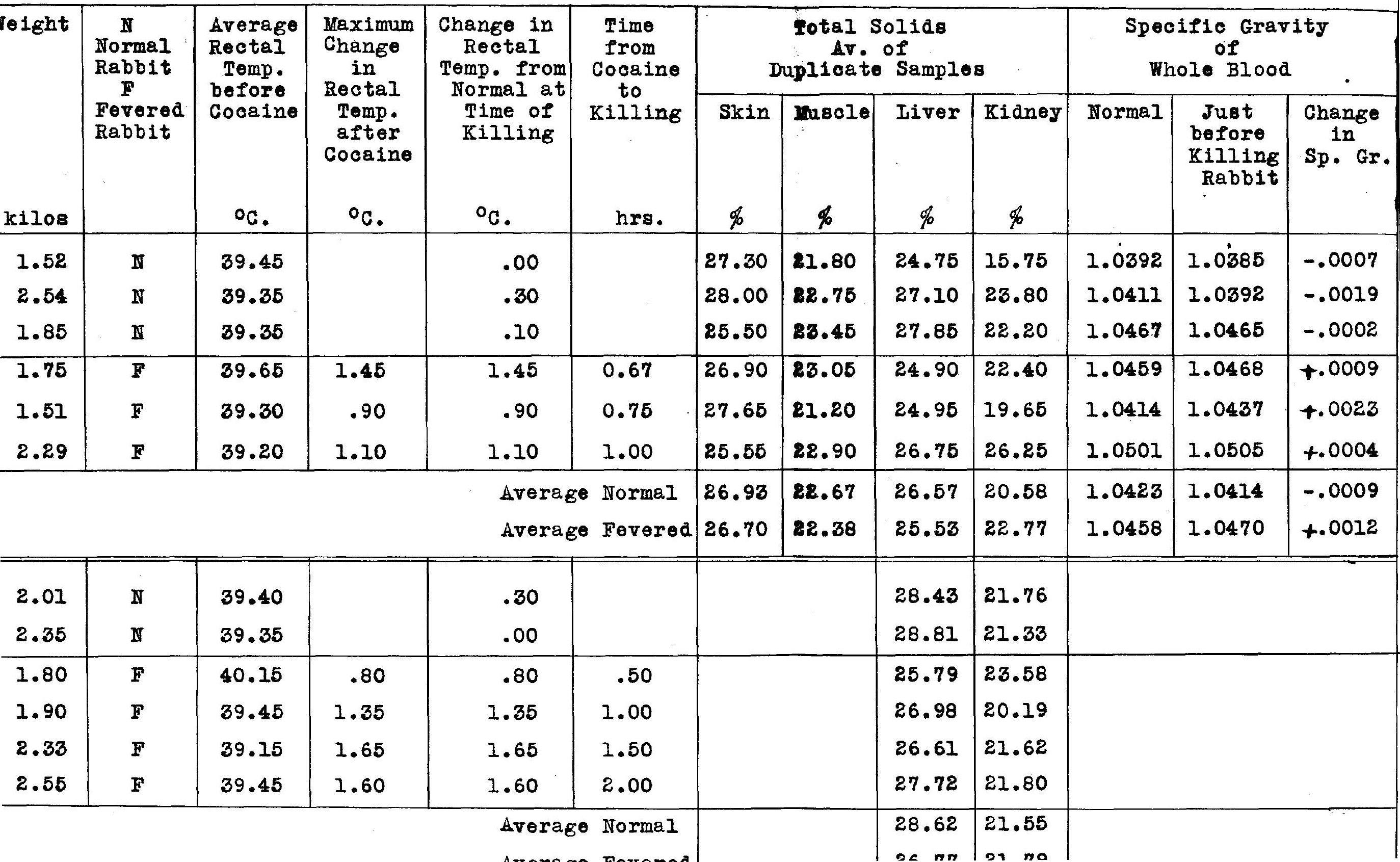


Table 5.

Summary: Tissue Solids of Normal and Cocaine Fever Rabbits.

\begin{tabular}{|c|c|c|c|c|c|c|c|}
\hline & \multicolumn{2}{|c|}{$\begin{array}{l}\text { Total Number } \\
\text { of } \\
\text { Determinations }\end{array}$} & \multicolumn{3}{|c|}{$\begin{array}{c}\text { Average } \\
\text { Total Solias }\end{array}$} & \multicolumn{2}{|c|}{$\begin{array}{l}\text { Standard } \\
\text { Deviation } \\
\text { of Average }\end{array}$} \\
\hline & $\begin{array}{l}\text { Normal } \\
\text { Control } \\
\text { Rabbits }\end{array}$ & $\begin{array}{l}\text { Fevered } \\
\text { Rabbits }\end{array}$ & $\begin{array}{c}\text { Normal } \\
\text { Control } \\
\text { Rabbits } \\
\%\end{array}$ & $\begin{array}{l}\text { Fevered } \\
\text { Rabbits }\end{array}$ & $\begin{array}{c}\text { Averago } \\
\text { Difference } \\
\text { between } \\
\text { Duplicate } \\
\text { Samples } \\
\% \\
\%\end{array}$ & $\begin{array}{l}\text { Normal } \\
\text { Control } \\
\text { Rabbits }\end{array}$ & $\begin{array}{l}\text { Fevered } \\
\text { Rabbits }\end{array}$ \\
\hline Basal Ganglia & 8 & 11 & 23.49 & 23.23 & 0.805 & \pm 0.17 & \pm 0.17 \\
\hline Medulla & 8 & 11 & 27.80 & 28.12 & 0.695 & \pm 0.12 & \pm 0.21 \\
\hline Cerebrum & 8 & 11 & 21.07 & 21.37 & 0.547 & \pm 0.88 & \pm 0.16 \\
\hline Skin & 10 & 11 & 27.06 & 28.46 & 1.652 & \pm 0.98 & \pm 0.82 \\
\hline Muscle & 8 & 9 & 22.84 & 22.78 & 0.306 & \pm 0.19 & \pm 0.30 \\
\hline Liver & 9 & 12 & 28.14 & 26.03 & 0.419 & \pm 0.58 & \pm 0.29 \\
\hline Kioney & 5 & 7 & 20.97 & 22.21 & 1.142 & \pm 1.57 & \pm 0.84 \\
\hline
\end{tabular}


the average of all normal and all fevered rabbits respectiveIy, checks also the hiological varfability of the animals. A glance at table five will show that the variations between animals are remarkably small in all the tissues studied except the skin and kidney.

Brain: No significant change in total solids from the determined normal was found in any of the three anatomical divisions of the brain studied. These three, basal, ganglia, medulla and cerebrum include most of the brain tisgue and would undoubtedly show the change if one occurred. The average difference in duplicate samples is well under one percent in all three divisions indicating that the technical error is not so great as to overshedow any significant change. The standard deviation from the average is algo small showing that the mimals are comparable.

Skin: The large variation between "duplicate" samples and the relatively high standerd deviation of the average of these determinations seems to preclude any positive conclusions. The apparent increase of over one percent in total solids would indicate however, that the skin does not at any rate take up water after cocaine. 
Muscle: The total solids of skeletal muscle agree very closely for normal and fevered rabbits. The techical error and the standard deviation of the average are both low. Evidently the skeletal musclature plays no part in the water shift following pyretic doses of cocaine. Liver: In the group of rabbits in Table 3 the average total solids of the IIver for the fevered rabbits is $3.3 \%$ lower than in the normal controls. In Table $4 \mathrm{~A}$, the fevered rabbits are slightly over $1.0 \%$ lower while in Table 4B they are about 2. $0 \%$ lower. Figure 2 is plotted from Table 4B. The average for the entire series from Table 5 shows that the liver solids are decreased by $2.11 \%$ from the normal control average. The percentage tatal solids is 28.14 for the fovered rabbits as against 36.03 for normal rabbita, showing, therefore, a $7.50 \%$ decreas $\theta$. The average difference between duplicate semples is less than one-half of one percent while the standard deviation of the average of the entire series of animals is relatively insignificant in face of such a large decrease in solids. rhis decrease is solids must be brought about by an increase in the fluid content of the liver. Figure 2 shows that this is most marked at one-half hour more or less after the injection of the pyretic dose of cocaine, the effect still persisting after two hours. 


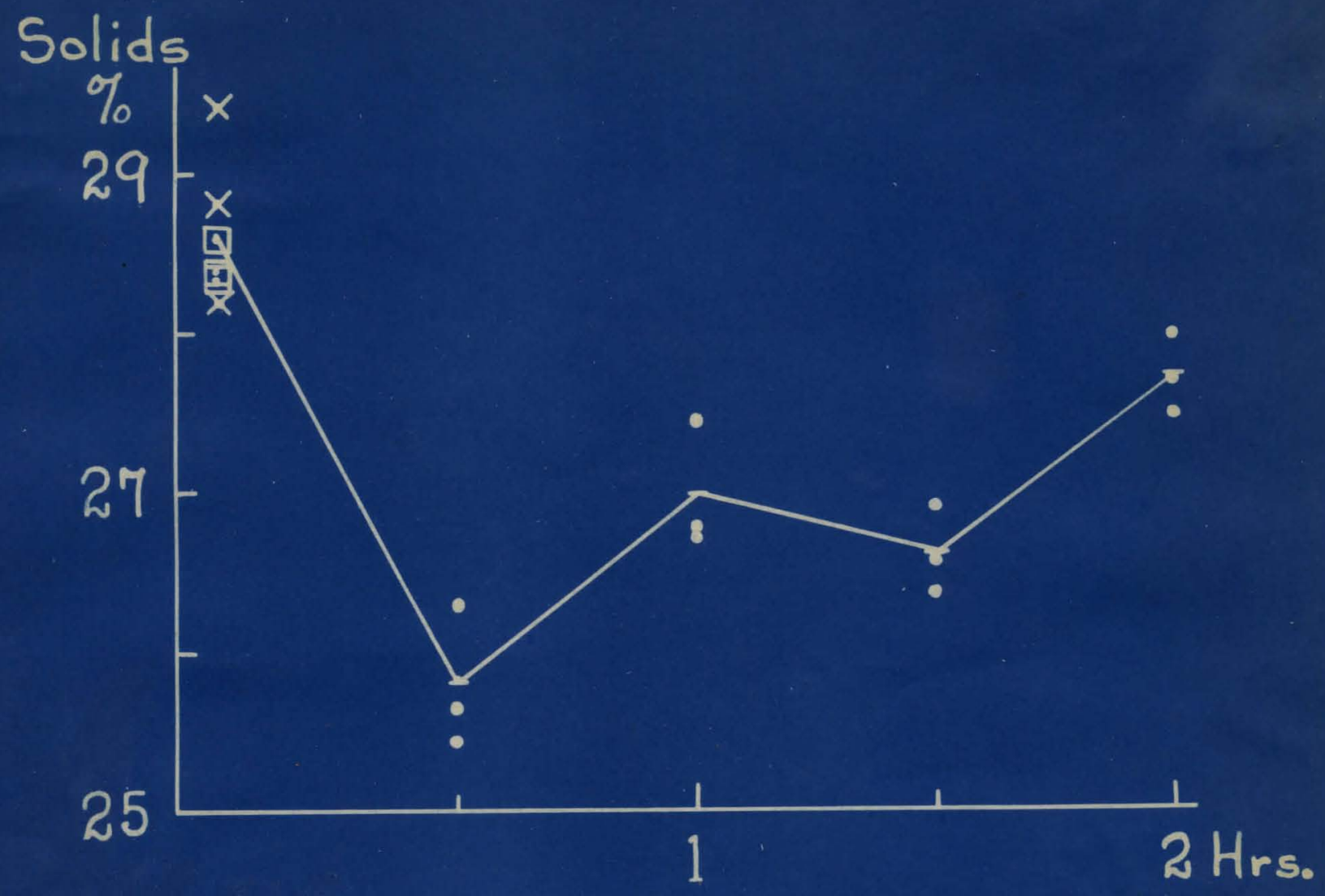

Fig. 2. Showing effects of cocaine, (40 mgm. per kilo) on total solids of liver.

Crosses and squares at left represent solids of three samples of liver from each of two normal control rabbits. Crosses represent Rabbit No. 102 and squares Rabbit No. 100.

Dots represent solids of three samples of liver from each of four fevered rabbits. The continuous line is plotted through an average of these points.

Abscissae, time from injection of cocaine to taking of samples.

From Table 4B. 
Kidney: These results, like those upon the skin are extremely variable. It was practically impossible to secure duplicate samples which would agree within the limits of error of the gravimetric method employed. Also the variability between animals which were satisfactorily comparable for the study of other tissues was so great as to invalidate the results. However, one can see no reason to believe that there is an increase in the fluid content of the kidney after cocaine, and some decrease possibly occurs. B. Body Cavities.

An attempt was made to determine the fluid content of the perficardial, pleural and peritoneal cavities in normal control ahimals and in fevered animals. The cavities were carefully opened and the fluid caused to drain to the lowest point in each cavity. After allowing one or two minutes for drainage, attempts were made to recover and measure the fluid in a small fine tipped pipette.

Usually it was impossible to recover a measurable quantity of fluid in elther of the three cavities. In a few normal and a few fevered animals 0.1 to 0.2 cubic centimeters was recovered from the peritoneal cavity. In no cases did there seem to be any relation between the amount of recoverable fluid and fever. This indicates that there is no inerease in the fluid content of either of the three cavities following pyretic doses of cocaine. 


\section{DISCUSSION.}

During the rige in temperature produced by cocaine in rabbits the blood is more concentrated due to a decrease in plasma rather than an increase in cells. Existing evidence painted toward water shift within the body.. As pointed out earlier in this paper there seemed to be good reason to look for part, at least, of this flufd in the brain. The above results show that it does not go there. The motor activity and other central factors predisposing to fever therefore must be ascribed to a direct effect of the alkaloid upon the brain cells, ungupported by hydration.

The importance of the skin in the heat regulating mechamism is universally recognized. Thet fluid might be stored in the skin during the rise in body temperature, thus affecting the ability of the organism to eliminate heat seemed possible. The above results indicate, at least, that the skin does not store water in cocaine fever and show that the skin may even become drier during the rise in temperature.

The large bulk of the skeletal musculature makes it a storehouse for large quantities of water. That the water lost from the blood stream could easily be stored there with a possible effect upon heat production seemed within reason. Results of the above series of experiments show, however, that there is no change in the water content of the skeletal musculature after cocaine. 
Lamson (14) has emphasized the role of the liver in the regulation of blood volume and has shown that following epinephrin fluid escapes from the blood into the liver lymphatics. It is known that the liver aids in the destruction of cocaine within the body.(15) In our experiments, out af all the possible places of storage of water lost from the blood following pyretic doses of cocaine the only one showing a significant change in water content is the Ifver.

Is this storage of water in the liver then due to an epinephrin like effect of cocaine or to the toxio effects of the cocaine upon the liver cells? In this connection Ehrlich (16) has shown that the livers of mice, following the continued administration of cocaine, are greatly increased in size, anemic in appearance and show upon mioroscopical examination all stages of cell degeneration, the most striking change being a vacuolar degeneration of the cell protoplasm. Wallace and Diamond (17) studied the effect of cocaine on the liver of a series of animals of different species. The cocaine was administered over periods of two to thirty days in doses sufficient to induce typical cocaine symptoms. Vacuolar degeneration was found in the rat and guinea pig while in the rabbit, dog and cat the most striking change was a wide spread granular degeneration. The rabbit's liver was enlarged and pale, the cells being enlarged and the nucleus surrounded by more or less clear zones containing a varying number of granules. There was no evidence of an inflammatory reaction and 
the nuclei were unaffected. Gilbert and Carnot (18) in studies on the effect of the chronic action of scarcely toxic doses of cocaine in rabbits obtained a vacuolar and fatty degeneration of the endothelial, hepatic and biliary cells, the most noticeable effect being upon the endothelial cells of the liver. They also found that the liver was often heavier than normal. In view of the above, the increase in water content of the liver is evidentIy associated with direct toxic changes and it is unnecessary to postulate in addition a sympathetic nerve effect. Our experiments show that there is a shift of water within the body during the rise in temperature following pyretic doses of cocaine. Water is transferred from the blood to the liver but to none of the other tissues or any of the body cavities studied. These results seem to agree well with the findings of Gilbert and Carnot (18), who, after repeated small doses of cocaine found no pathological change in any organs of the body except the liver. 
2. INVESTIGATIONS CONCERNING A POSSIBIE CHANGE IN THE RATE OF WATER LOSS FROAI THE BODY. 
II. Investigations Concerning a Possible Change in the Rate of Water Loss From the body.

Is water loss from the body increased by pyretic doses of cocaine?

Although the amount of water shifted to the liver, as shown in Part I, is probably sufficient to account for the blood concentration, other exchanges are by no means precluded. In cases where there is a known disturbance of the heat balance of the body, it is particularly pertinent to look for changes in the rate of vaporization.

A. Vaporization of water from the body: A study of the "Insensible Loss."

The "insensible loss" of weight has been defined by Isenschmid (19) as equal to the weight of the water vaporized. plus the carbon dixide excreted minus the oxygen absorbed. Evidently determinations of the gaseous exchange are necessary - to a calculation of the water balance as of the heat balance. Such obeervations: were therefore made in conjunction with the study of the body weight.

\section{METHODS.}

Plabbits of the same stock and age as those employed in the study of tissue solids were used. Atmospheric conditions were meintained as nearly constant as possible but in some experiments, due to a change in season it was impossible to maintain 
a dry bulk temperature as low as previously used. However, cooling power was maintained within limits considered comfortable for man. As measured by the wet Kata-thermometer it varied in all the experiments only from 14.5 to 19.3 milli calories per sq. cm. per second. Cireulation of air was maintained by a small fan, not blown directly upon the animal. To avoid marked convulsive effects, the dose of cocaine was reduced from 40 milligrams per kilo used in the tissue studies to about 30 milligrams per kilo in the metabolism work. This smaller dose gave a typical reaction to cocaine; feeble convulsions were sometimes observed. The rise in rectal temperature occurred as promptly as after the larger dose.

The weight loss was determined by suspending the animal, in a light wire basket, from a balance sensitive to 0.1 gram. In most experiments weights were taken every half hour, while in a f'ew cáses hourly periods were used. By careful massage of the bladder and rectum at the beginning of the experiment,enough urine and feces were forced out so that these factors rarely complicated the welght loss. A pan suspended under the basket facilitated the detection of any evacuation. If evacuation did occur, the last previous weight was discarded; the exereta removed and a new period started. In none of the experiments described in this paper were urine or feces evacuated after cocaine administration.

Rectal temperature readings were taken as described previously with care to avoid adding to or subtracting from the animals welght during this procedure. 
In determining the respiratory exchange the expired air was collected in a very light rubber bag, the inflation of which offered very little resistance to: expiration. A mask, made from the light metal cap of a thermos bottle, was fitted tightly over the rabbit's face at least an hour before the beginning of collection of samples for analysis. This mask was connected through a T-tube to the rubber beg. The inspiratory and expiratory valves were made of sausage casing as described by Pearce (20). It was found that this system offered very little resistance to the animals breathing and that after a short preliminary period of excitement when the mask was applied the animal became quiet and appeared to breathe normally, without effort.

After the animal had remained quiet for at least an hour, the experiment was begun. The body weight was taken with the mask in place, the rectal temperature recorded and the $T$-tube connected with the mask. The animal was allowed to breathe through the valves for a few minutes, after which expired air was collected in a basketball bladder until it was about half full. It was then disconnected and the large soft rubber bag connected to the T-tube. The expired air was collected in this bag for exactly fifteen minutes after which the partly filled basket-ball bladder was again substituted. After filling was completed samples were taken from it for immediate analysis. Thes a few minutes remained in each period for weighing and taking the rectal temperature. 
To obtain the volume of expired air the contents of the light rubber bag were run through a gas meter. The volume for the half hour period was assumed to be just twice the amount measured, while the samples from the basket-ball bladder were considered representative of a mixed sample of expired air for the period.

Following several normal periods and just after a final normal rectal temperature reading the cocaine was injected and the animal followed for severel more periods. The exact weight of the cocaine solution injected was taken into account at the noxt weighing.

Samples. of expired air were analyzed immediately after collection in order to guard against a change in composition due to diffusion through the walls of the basket-ball bladder. Analyses were made on each sample in duplicate in a Haldane respiratory gas analyzer as described by Henderson (21) whose method of calculation was followed.

Both insensible loss and metalbolism have been expressed in terms of surface area. Surface area of the rabbits was calculated by the Rubner-Meek formula: $0.125 \sqrt[3]{W^{2}}$ (22) where $\mathrm{W}$ represents the body weight. RES UL T S.

The results of five experiments on the effiect of pyretic doses of cocaine upon the rate of insensible loss are given as follows: 


$$
\begin{aligned}
& \text { Exp. } 1 \text { in Table } 6 \text { and Fig. } 3 \\
& \text { Exp. } 2 \text { in Table } 7 \text { and Fig. } 4 \\
& \text { Exp. } 3 \text { in Table } 8 \text { and Fig. } 5 \\
& \text { Exp. } 4 \text { in Table } 9 \text { and Fig. } 6 \\
& \text { Exp. } 5 \text { in Table } 10 \text { and Fig.7. }
\end{aligned}
$$

In Exp. I no data on the respiratory exchange were taken while in all the other experiments given, the change in weight due to $\mathrm{CO}_{2}-\mathrm{O}_{2}$ was taken into account, giving in addition the expired air volume and the total heat production. Atmospheric conditions and rectal temperatures are given for each experiment.

What are the effects of pyretic doses of cocaine upon the insensible loss? In a study of the entire series it is plainly seen that the loss due to vaporization of water is not greatiy changed during the first half hour after the cocaine injection. But it is during this first period that the blood concentration occurs as shown previously in Fig. 1. Also it is during this first half hour that the sharpest rise in the fever curve takes place. In Exp. 1, the total Insensible loss for each of the three hours after the cocaine was less than the average for the two hours previous to the cocaine. In Exp. 2, the total insensible loss was increased by $71.6 \%$ while the Ioss: due to vaporization of water was increased by $42.9 \%$. (In this 
Table 6 .

Effect of Cocaine upon Total Insensible Los8. Rabbit. Surface Area $0.211 \mathrm{Sq} . \mathrm{M}$.

\begin{tabular}{|c|c|c|c|c|}
\hline & \multicolumn{2}{|c|}{$\begin{array}{l}\text { Atmospherio } \\
\text { Conditions }\end{array}$} & \multirow{2}{*}{$\begin{array}{c}\text { Rectal } \\
\text { Temp. } \\
{ }^{\circ} \mathrm{C} .\end{array}$} & \multirow{2}{*}{$\begin{array}{c}\text { Weight Los } \\
\text { Per } \\
\text { Sq. Meter } \\
\text { Per Hour } \\
\text { Gms. }\end{array}$} \\
\hline & $\begin{array}{c}\text { Room } \\
\text { Temp } \\
\text { OC. }\end{array}$ & $\begin{array}{c}\text { Relative } \\
\text { Humidity } \\
\%\end{array}$ & & \\
\hline $1: 00$ & 24.5 & 41 & 38.55 & \\
\hline $2: 00$ & 25.0 & 42 & 38.80 & 11.37 \\
\hline $3: 00$ & 25.0 & 42 & 38.90 & 12.56 \\
\hline $3: 01$ & \multicolumn{4}{|c|}{ Cocaine-HCl $20 \mathrm{mgm}$. per kilo } \\
\hline $4: 00$ & 25.0 & 42 & 39.65 & 9.00 \\
\hline $5: 00$ & 26.0 & 40 & 39.80 & 9.95 \\
\hline $6: 00$ & 25.2 & 43 & 40.00 & 9.00 \\
\hline
\end{tabular}




\section{Grms./Sq.M./Hr.}
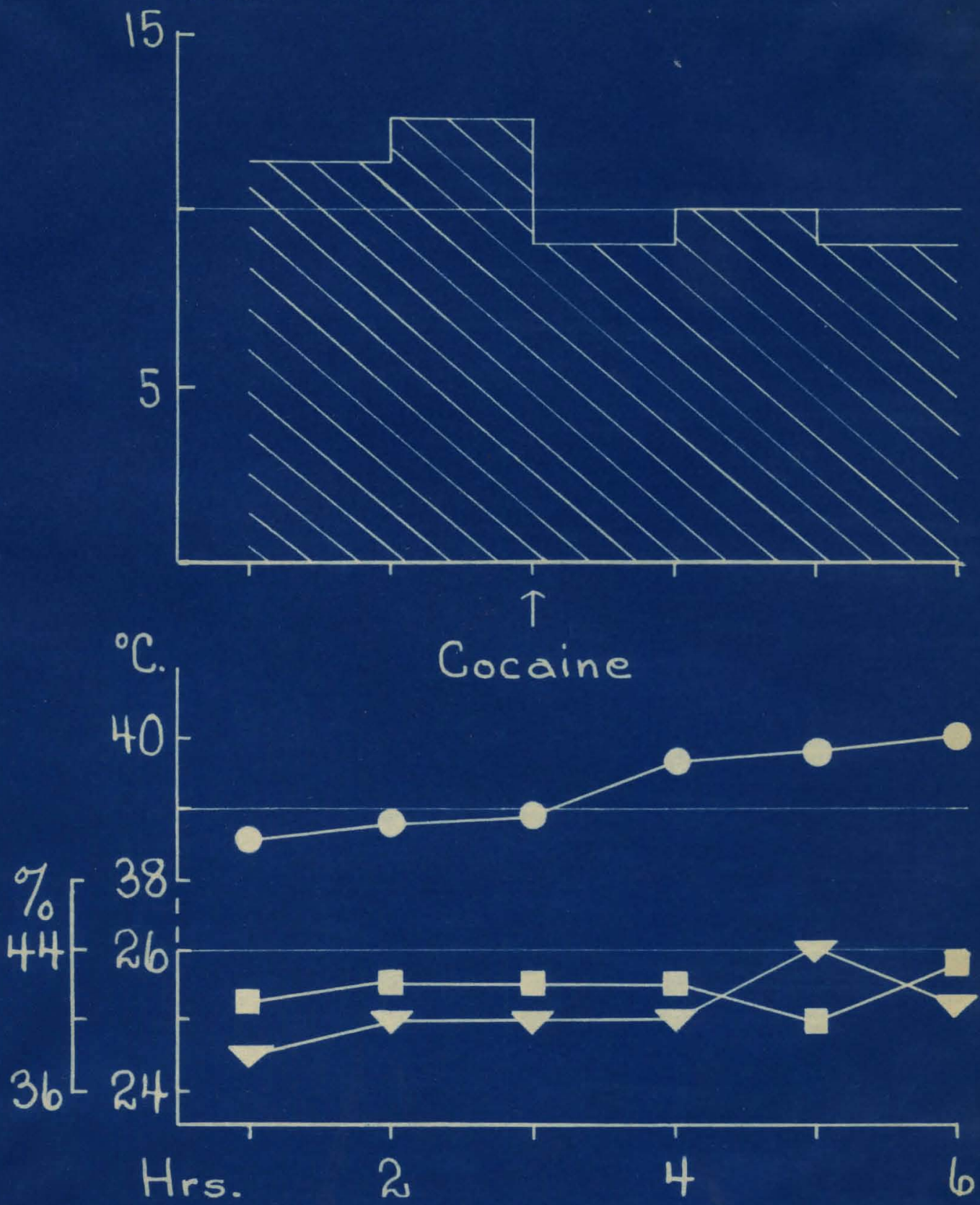

Fig. 3. Showing effects of cocaine (20 mgm. per kilo) on total insensible loss.

Abscissae: Time in hours.

Ordinates: Room temperature, ${ }^{\circ} \mathrm{C}$. ; relative humidity in per cent saturation; rectal temperature, ${ }^{\circ} \mathrm{C}$; total weight loss in grams per square meter per hour.

Triangles represent room temperature.

Squares represent relative humidity.

Large dots represent rectal temperature. 
Legend to Figures $4,5,6$ and 7 .

Showing effects of cocaine, 20.0,27.3, 27.3 and 30 mgms. per kilo respectively, on total insensible loss and metabolism.

Abscissae: Time in hours.

Oridinates: Cooling power expressed in millicalories per square centimeter per second (all except Figure 4); room temperature ${ }^{\circ} \mathrm{C}$; relative humidity in percent saturation; rectal temperature in ${ }^{\circ} \mathrm{C}$; insensible loss in grams per square meter per hour; tatal heat production in calories per square meter per hour; respiratory quotient; expired air volume in liters per hour for the enimal.

Small dots represent cooling power.

Squares represent relative humidity.

Triangles represent room temperature.

Large dots represent rectal temperature.

Shaded areas represent insensible loss due to vaporization of water.

Heavy line represents total insensible loss.

Areas between heavy line and shaded area, represents insensible loss due to $\mathrm{CO}_{2}-\mathrm{O}_{2}$.

Triangles with apex at top represent respiratory quotient.

Broken line represents expired air volume.

Heavy line represents total heat production. 
Table 7 .

Effect of Cocaine upon Insensible Ioss and Total Metabolism.

Rabbit. Surface Area $0.25 \mathrm{Sq} . \mathrm{M}$.

\begin{tabular}{|c|c|c|c|c|c|c|c|c|c|c|c|}
\hline \multirow[t]{2}{*}{ P.M. } & \multicolumn{2}{|c|}{$\begin{array}{l}\text { Atmospherie } \\
\text { Conditions }\end{array}$} & \multirow{2}{*}{$\begin{array}{r}\text { Rectal } \\
\text { Temp. } \\
{ }^{\circ} \mathrm{C} .\end{array}$} & \multirow{2}{*}{$\begin{array}{c}\text { Expired Air } \\
\text { Volume } \\
\text { Per Hour } \\
\mathrm{f}^{\circ} \mathrm{C} \text { \& } 760 \mathrm{~mm} \\
\\
\text { Iiters }\end{array}$} & \multicolumn{3}{|c|}{$\begin{array}{l}\text { Insensible I0ss } \\
\text { Per Sq.M. Per Hour }\end{array}$} & \multicolumn{4}{|c|}{ Total Metabolism } \\
\hline & $\begin{array}{c}\text { Room } \\
\text { Temp. } \\
{ }^{\circ} \mathrm{C} .\end{array}$ & $\begin{array}{c}\text { Relative } \\
\text { Humidity } \\
\%\end{array}$ & & & $\begin{array}{l}\text { Total } \\
\text { Gms. }\end{array}$ & $\begin{array}{l}\text { Due to } \\
\mathrm{CO}_{2}-\mathrm{O}_{2} \\
\text { Gms. }\end{array}$ & $\begin{array}{c}\text { Due to } \\
\mathrm{H}_{2} \mathrm{O} \\
\text { Vaporized } \\
\text { Gms. }\end{array}$ & $R \cdot Q$. & $\begin{array}{l}\text { Iters } \\
\mathrm{CO}_{2}\end{array}$ & $\begin{array}{c}\text { Iters } \\
\mathrm{O}_{2}\end{array}$ & $\begin{array}{l}\text { Cal. Per } \\
\text { Sq.M. Per Hour }\end{array}$ \\
\hline $1: 50$ & 24.0 & 39 & 39.65 & & & & & & & & \\
\hline $2: 50$ & 24.0 & 39 & 89.40 & & & & & & & & \\
\hline $3: 50$ & 24.5 & 39 & 39.45 & 49.75 & 13.05 & 1.15 & 11.89 & 0.814 & 1.298 & 1.592 & 30.74 \\
\hline $3: 55$ & Cocair & DO-HCI 20 & mgms. & per kilo & & & & & & & \\
\hline $4: 50$ & 25.0 & 40 & 40.80 & 90.00 & 22.40 & 5.41 & 16.99 & 1.040 & 2.445 & 2.438 & 49.27 \\
\hline $5: 50$ & 25.0 & 41 & 39.65 & 84.50 & 28.80 & 1.38 & 27.42 & 0.815 & 1.550 & 1.910 & 36.82 \\
\hline
\end{tabular}


Expired Cals.

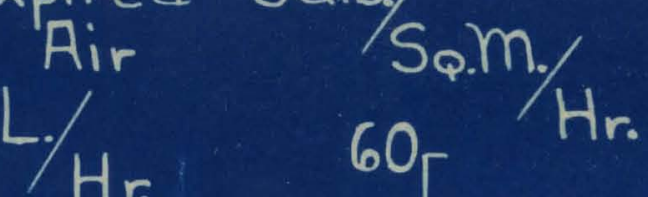

$\mathrm{Hr}$.

$600^{-1.00-}-0.80-5$.

Gms. $/ 5$. m. $/ \mathrm{Hr}$.

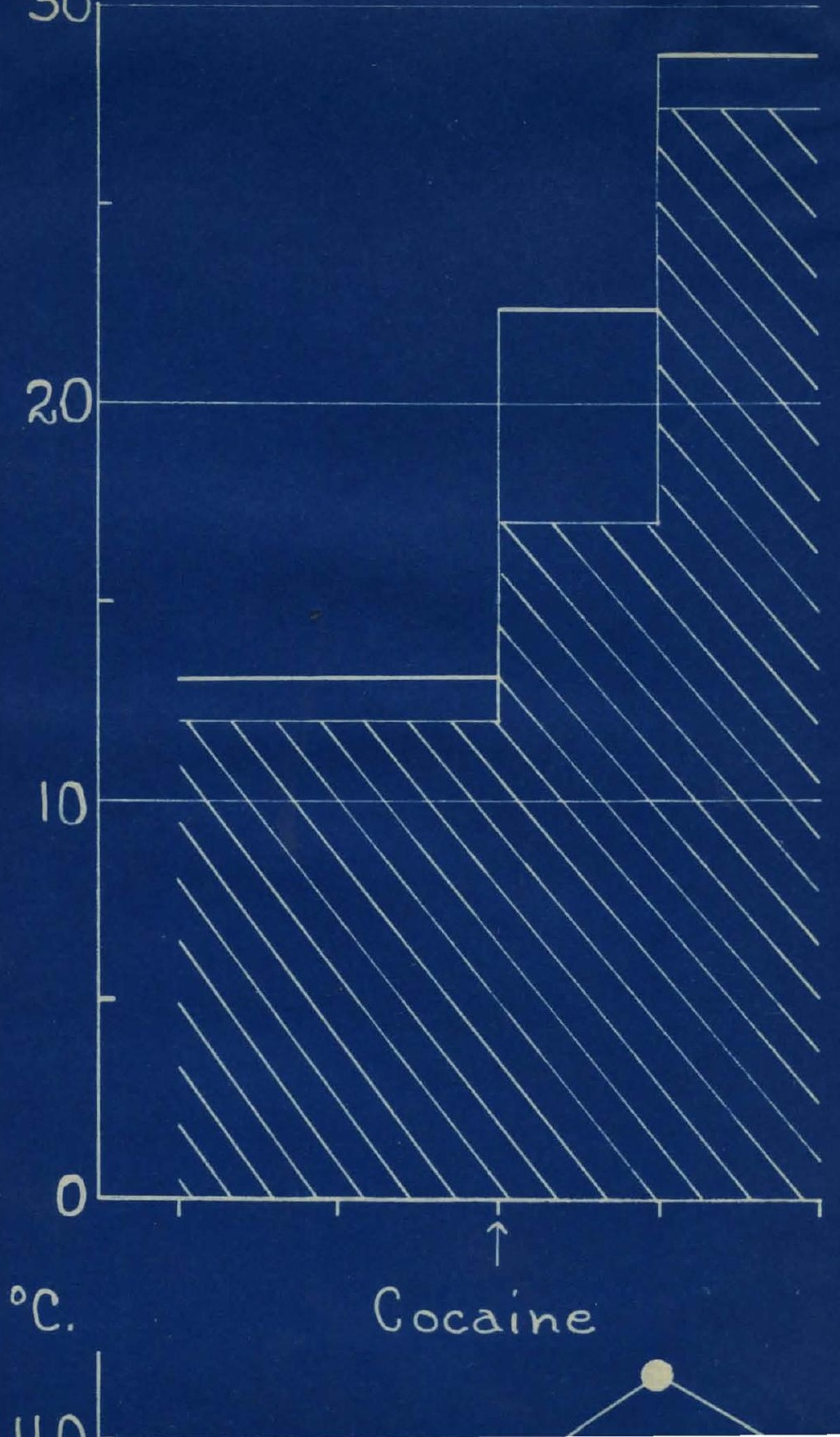




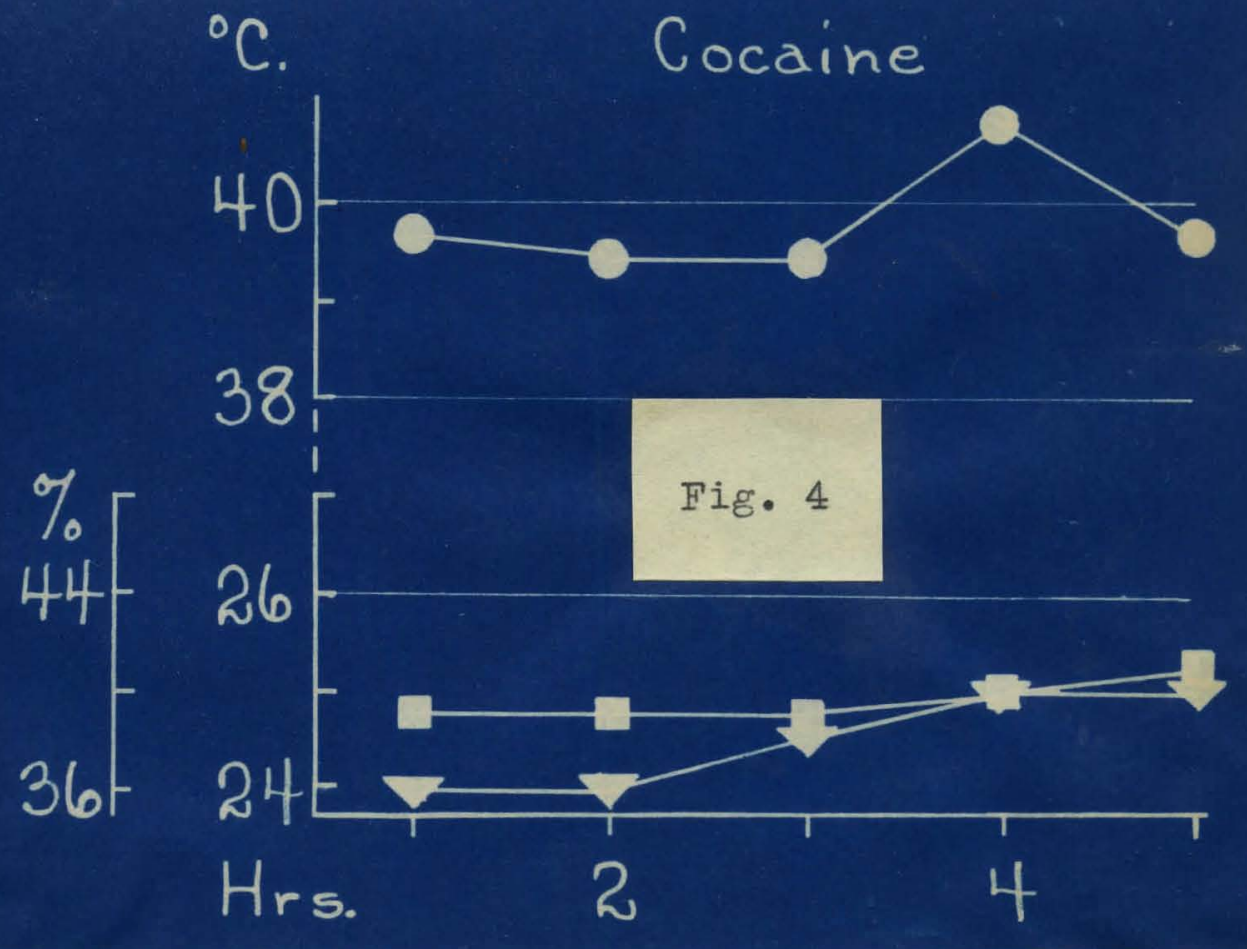


Table 8.

Effect of Cocaine upon Insensible Loss and Total Metabolism Rabbit. Surface Area 0.211 Sq.M.

\begin{tabular}{|c|c|c|c|c|c|c|c|c|c|c|c|}
\hline \multicolumn{3}{|c|}{$\begin{array}{l}\text { Atmospheric } \\
\text { Conditions }\end{array}$} & \multirow{2}{*}{$\begin{array}{c}\text { Rectal } \\
\text { Temp. } \\
\\
{ }^{\circ} \mathrm{C} .\end{array}$} & \multirow{2}{*}{$\begin{array}{c}\text { Expired Air } \\
\text { Volume } \\
\text { Per Hour } \\
0^{\circ} \mathrm{C} \text { \& } 760 \mathrm{~mm} . \\
\text { Liters }\end{array}$} & \multicolumn{3}{|c|}{$\begin{array}{l}\text { Insensible I0ss } \\
\text { Per Sq.M. Per Hour }\end{array}$} & \multicolumn{4}{|c|}{ Total Metabolism } \\
\hline $\begin{array}{l}\text { Room } \\
\text { Temp. }\end{array}$ & $\begin{array}{l}\text { Relative } \\
\text { Humidity }\end{array}$ & $\begin{array}{c}\text { Cooling } \\
\text { Power } \\
\text { in } \\
\text { Millical. } \\
\text { Per } \\
\text { Sq. Cm. } \\
\text { Per Sec. }\end{array}$ & & & $\begin{array}{c}\text { Total } \\
\text { Gms. }\end{array}$ & $\begin{array}{l}\text { Due to } \\
\mathrm{CO}_{2}-\mathrm{O}_{2}\end{array}$ & $\begin{array}{c}\text { Dre to } \\
\mathrm{H}_{2} \mathrm{O} \\
\text { Vaporized }\end{array}$ & R.Q. & $\begin{array}{l}\text { Liters } \\
\quad \mathrm{CO}_{2}\end{array}$ & $\begin{array}{c}\text { Liters } \\
\mathrm{O}_{2}\end{array}$ & $\begin{array}{c}\text { Cal. Per } \\
\text { Sq.M. Per Hour }\end{array}$ \\
\hline 30.0 & 40 & 15.45 & 39.35 & & & & & & & & \\
\hline 30.2 & 40 & 16.85 & 39.55 & 59.97 & 10.43 & 0.274 & 10.156 & 0.744 & 1.053 & 1.417 & 31.78 \\
\hline \multicolumn{12}{|c|}{ Cocaine-HCl $27.3 \mathrm{mgms}$. per kild } \\
\hline 30.6 & 39 & 16.35 & 40.45 & 63.20 & 9.48 & 0.035 & 9.445 & 0.725 & 1.182 & 1.630 & 36.36 \\
\hline 30.8 & 39 & 16.74 & 40.45 & 74.60 & 19.92 & -0.251 & 20.171 & 0.710 & 1.230 & 1.738 & 38.68 \\
\hline 30.8 & 39 & 15.97 & 41.30 & 86.60 & 17.06 & -0.062 & 17.122 & 0.720 & 1.351 & 1.079 & $41: 85$ \\
\hline 30.8 & 38 & 16.80 & 41.45 & 74.00 & 18.96 & 1.417 & 17.543 & 0.828 & 1.243 & 1.501 & 36.78 \\
\hline 30.6 & 38 & 16.35 & 41.45 & 63.85 & 23.70 & 3.858 & 19.842 & 1.130 & 1.136 & 1.003 & 23.96 \\
\hline
\end{tabular}


Expired

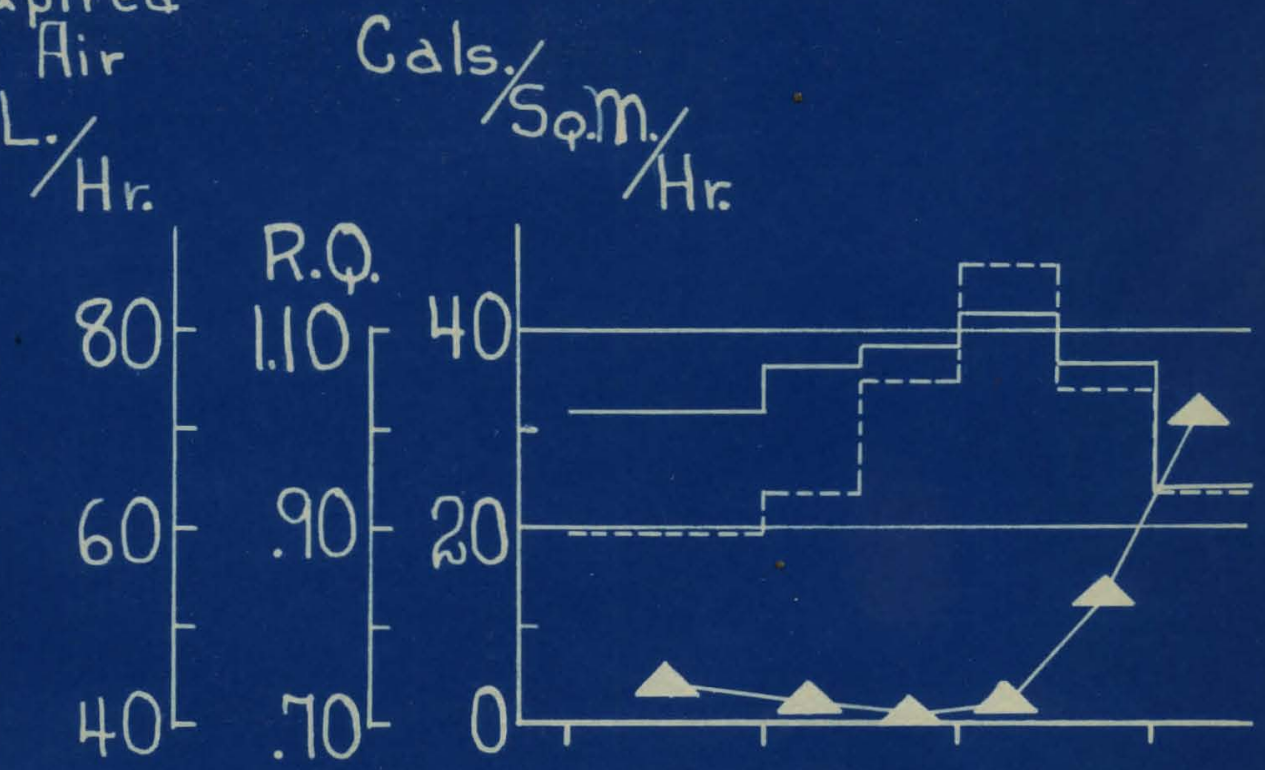

Gms
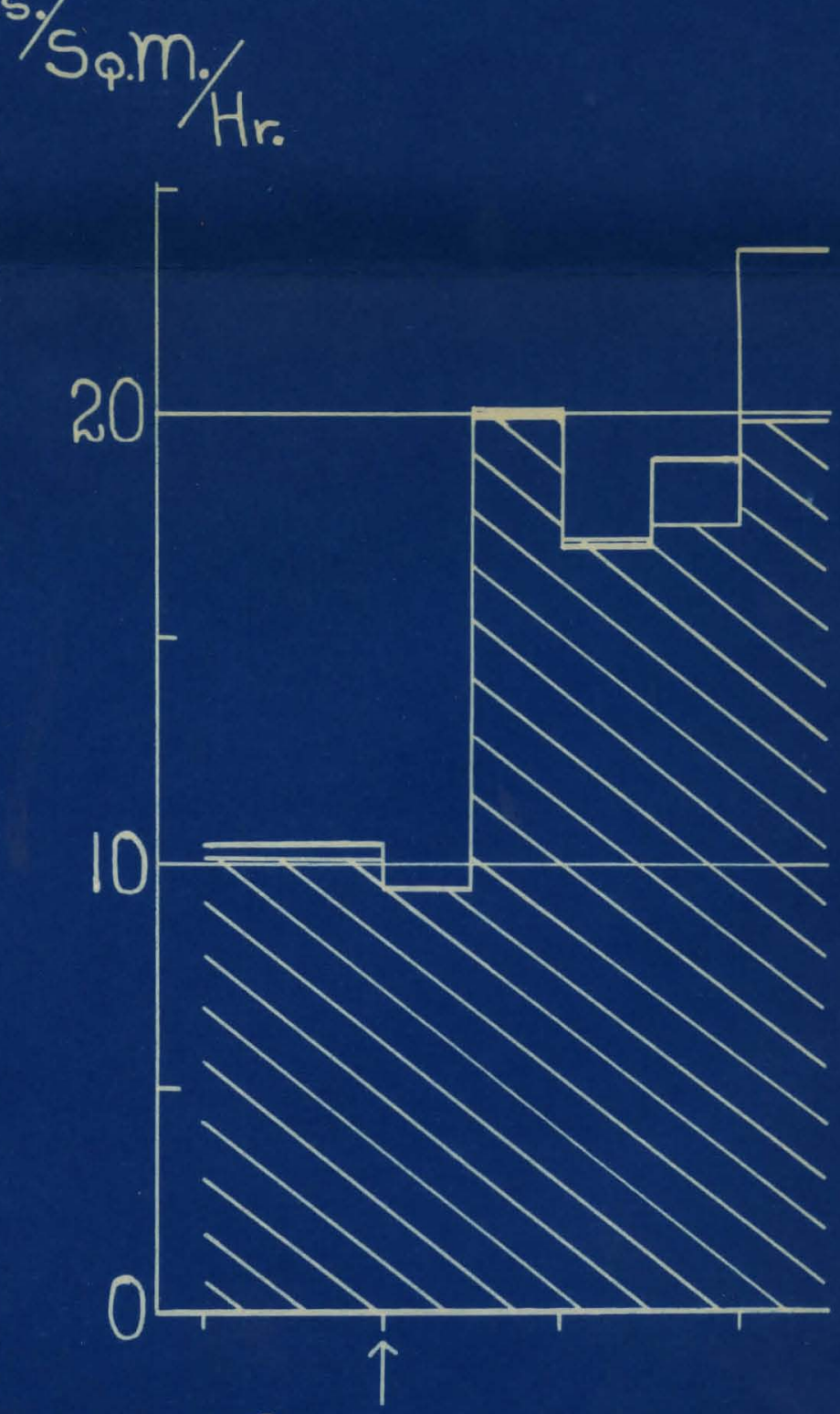

Cocaine 
Table 9.

Effect of Cocaine upon Insensible Loss and Total Metabolism.

Rabbit. Surface Area 0.211 Sq.M.

\begin{tabular}{|c|c|c|c|c|c|c|c|c|c|c|c|}
\hline \multicolumn{3}{|c|}{$\begin{array}{l}\text { Atmospheric } \\
\text { Conditions }\end{array}$} & \multirow[t]{2}{*}{$\begin{array}{l}\text { Rectal } \\
\text { Temp. }\end{array}$} & \multirow{2}{*}{$\begin{array}{c}\text { Expired Air } \\
\text { Volume } \\
\text { Per Hour } \\
0^{\circ} \mathrm{C} \text { \& } 760 \mathrm{~mm} .\end{array}$} & \multicolumn{3}{|c|}{$\begin{array}{l}\text { Insensible Loss } \\
\text { Per Sq.M. Per Hour }\end{array}$} & \multicolumn{4}{|c|}{ Total Metabolism } \\
\hline $\begin{array}{l}\text { Room } \\
\text { Temp. }\end{array}$ & $\begin{array}{l}\text { Relative } \\
\text { Humidity }\end{array}$ & $\begin{array}{c}\text { Cooling } \\
\text { Power } \\
\text { in } \\
\text { Milifical. } \\
\text { Per } \\
\text { Sq. Cm. } \\
\text { Per Sec. }\end{array}$ & & & Total & $\begin{array}{l}\mathrm{Du} \theta \text { to } \\
\mathrm{CO}_{2}-\mathrm{O}_{2}\end{array}$ & $\begin{array}{c}\text { Due to } \\
\mathrm{H}_{2} \mathrm{O} \\
\text { Vaporized }\end{array}$ & R.Q. & $\begin{array}{l}\text { Iiters } \\
\mathrm{CO}_{2}\end{array}$ & $\begin{array}{c}\text { Liters } \\
\mathrm{O}_{2}\end{array}$ & $\begin{array}{c}\text { Cal. Per } \\
\text { Sq.M. Per Hour }\end{array}$ \\
\hline 30.2 & 39 & 14.68 & 40.45 & & & & & & & & \\
\hline 30.5 & 39 & 16.57 & 40.80 & 41.52 & 11.37 & 0.074 & 11.296 & 0.729 & 0.889 & 1.219 & 26.84 \\
\hline Cocaip & ne-HCl 27 & $3 \mathrm{mgms} . \mathrm{pe}$ & r kilo & & & & & & & & $\cdot$ \\
\hline 30.6 & 39 & 15.62 & 41.35 & 45.90 & 19.91 & -0.299 & 20.207 & 0.708 & 1.502 & 2.121 & 47.12 \\
\hline 30.8 & 39 & 14.95 & 42.20 & 67.00 & 25.60 & -0.156 & 25.752 & 0.714 & 1.393 & 1.949 & 43.40 \\
\hline 30.8 & 39 & 14.95 & 42.55 & 53.08 & 43.61 & -0.014 & 43.622 & 0.722 & 1.184 & 1.640 & 36.60 \\
\hline 31.0 & 38 & 25.08 & 42.85 & 51.05 & 36.02 & 0.664 & 35.360 & 0.768 & 1.230 & 1.602 & 36.18 \\
\hline 31.0 & 37 & 14.54 & 43.30 & 39.90 & 23.70 & 0.213 & 23.487 & 0.739 & 0.971 & 1.312 & 29.40 \\
\hline 30.9 & 37 & 15.61 & 43.40 & 75.80 & 19.91 & 3.223 & 16.685 & 0.882 & 1.917 & 2.175 & 50.26 \\
\hline 30.8 & 37 & 15.08 & 43.90 & 55.80 & 21.80 & 2.517 & 19.287 & 0.916 & 1.273 & 1.390 & 32.60 \\
\hline
\end{tabular}


Expired Air L./

Cals.

$1 / 5 q$

q.).

Hr.

60

$H_{r}$ R.Q. $80[1.10$ [ 40

$60-90-20$ $40^{\circ} .70^{\circ} \quad 0$

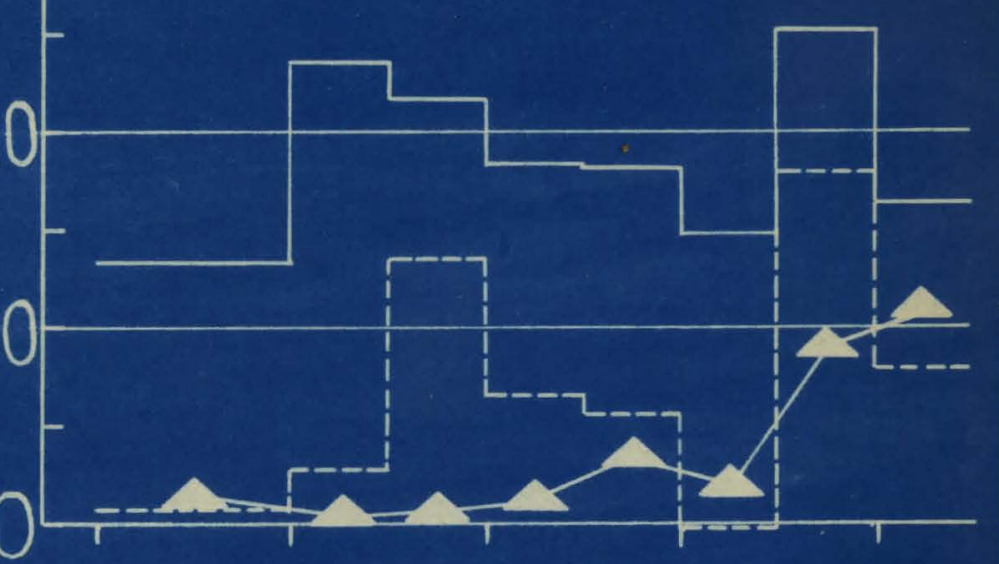

Gms.
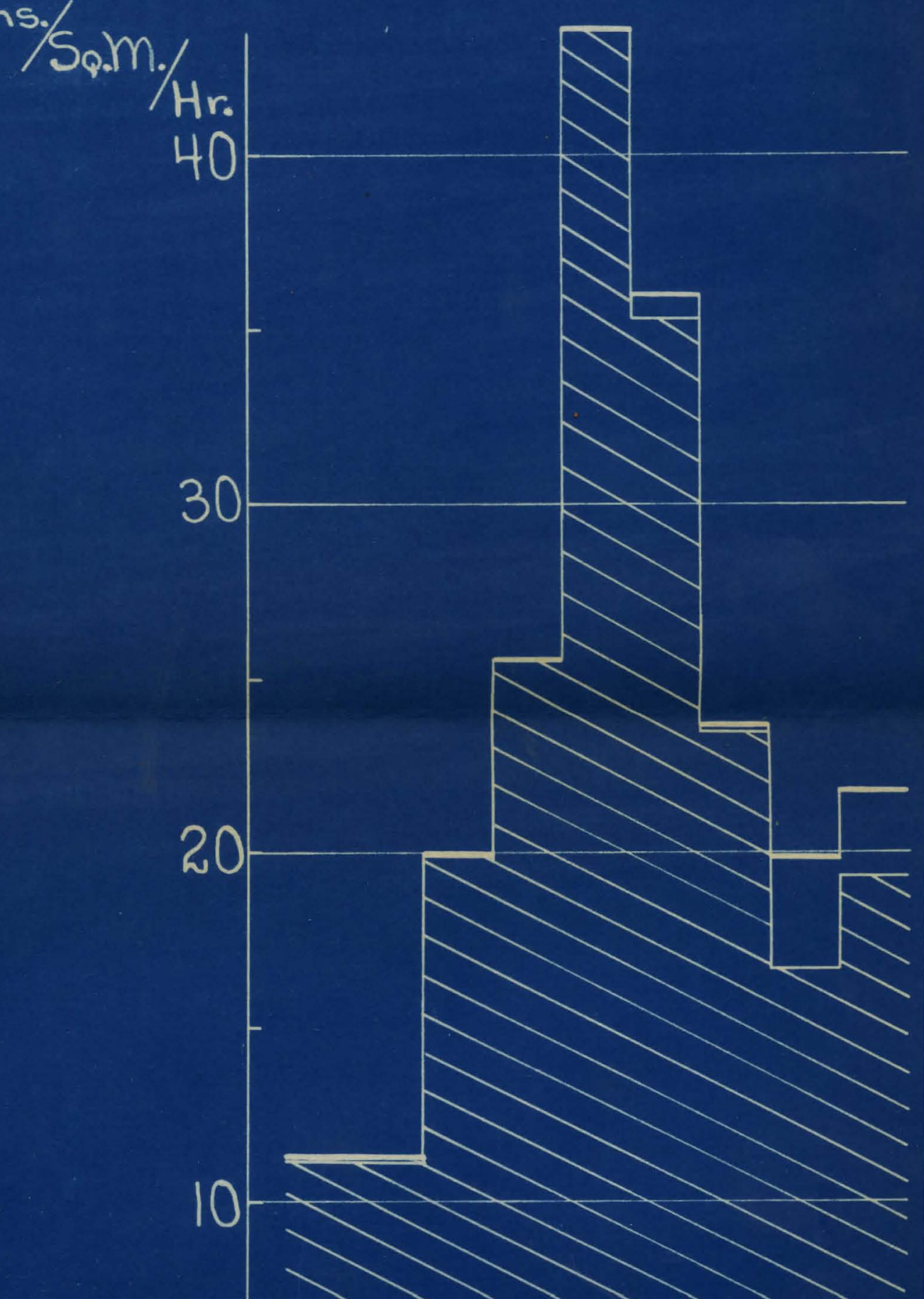
Table 10.

Effect of Cocaine upon Insensible Loss and Total Metabolism. Rabbit. Surface Area 0.198 Se.M.

\begin{tabular}{|c|c|c|c|c|c|c|c|c|c|c|c|}
\hline \multicolumn{3}{|c|}{$\begin{array}{l}\text { Atmospheric } \\
\text { Conditions }\end{array}$} & \multirow[t]{2}{*}{$\begin{array}{l}\text { Rectal } \\
\text { Temp. }\end{array}$} & \multirow{2}{*}{$\begin{array}{c}\text { Expired Air } \\
\text { Volume } \\
\text { Per Hour } \\
0^{\circ} \mathrm{C} \text {. \& } 760 \mathrm{~mm} .\end{array}$} & \multicolumn{3}{|c|}{$\begin{array}{l}\text { Insensible Tos8 } \\
\text { Per Sq.M. Per Hour }\end{array}$} & \multicolumn{4}{|c|}{ Total Motabolism } \\
\hline $\begin{array}{l}\text { Room } \\
\text { Tomp. }\end{array}$ & $\begin{array}{l}\text { Relative } \\
\text { Eumidity }\end{array}$ & $\begin{array}{c}\text { Cooling } \\
\text { Power } \\
\text { in } \\
\text { Mililoal. } \\
\text { Per } \\
\text { sq. Cm. } \\
\text { Per Sec. }\end{array}$ & & & Total & $\begin{array}{l}\text { Due to } \\
\mathrm{CO}_{2}-\mathrm{O}_{2}\end{array}$ & $\begin{array}{c}\text { Due to } \\
\text { HO }_{2} \\
\text { vaporized } \\
\text { Gms. }\end{array}$ & R.Q. & $\begin{array}{l}\text { Liters } \\
\mathrm{CO}_{2}\end{array}$ & $\begin{array}{l}\text { Liters } \\
\qquad 0_{2}\end{array}$ & $\begin{array}{c}\text { Cal. Per } \\
\text { Sq.M. Per Hour }\end{array}$ \\
\hline 30.5 & .46 & 19.25 & 40.10 & & & & & & & & \\
\hline 30.5 & 46 & 18.57 & 40.20 & 42.38 & 16.16 & 1.090 & 15.070 & 0.860 & 0.704 & 0.818 & 20.15 \\
\hline 30.3 & 46 & 18.86 & 40.45 & 64.75 & 17.17 & 0.465 & 16.705 & 0.758 & 1.028 & 1.358 & 32.57 \\
\hline 30.0 & 48 & 19.31 & 40.65 & 81.20 & 19.19 & 0.717 & 18.473 & 0.778 & 1.023 & 1.315 & 31.66 \\
\hline 29.8 & 48 & 15.11 & 40.40 & 71.58 & 19.19 & 2.166 & 17.024 & 0.902 & 1.102 & 1.224 & 30.45 \\
\hline 29.8 & 50 & 18.16 & 40.10 & 57.80 & 19.19 & 0.025 & 19.165 & 0.725 & 0.821 & 1.132 & 2689 \\
\hline 29.8 & 50 & 15.08 & 40.00 & 58.55 & 11.11 & -0.212 & 11.322 & 0.702 & 0.761 & 1.083 & $25.63^{\circ}$ \\
\hline Cocal & $\mathrm{ne-HCI} 30$ & mgms. per & kilo & & & & & & & & \\
\hline 29.5 & 50 & 17.84 & 40.90 & 77.20 & 14.14 & 1.384 & 12.756 & 0.812 & 1.266 & 1.559 & 37.90 \\
\hline 29.8 & 50 & 15.35 & 42.05 & 95.60 & 71.71 & 12.160 & 59.550 & 1.575 & 2.246 & 1.423 & 36.26 \\
\hline 30.0 & 54 & 16.50 & 43.10 & 86.65 & 15.15 & 2.586 & 12.564 & 0.896 & 1.342 & 1.498 & 37.27 \\
\hline 29.8 & 59 & 18.72 & 43.90 & 78.40 & 31.31 & 3.272 & 28.038 & 0.960 & 1.325 & 1.380 & 34.85 \\
\hline
\end{tabular}


20

0

10
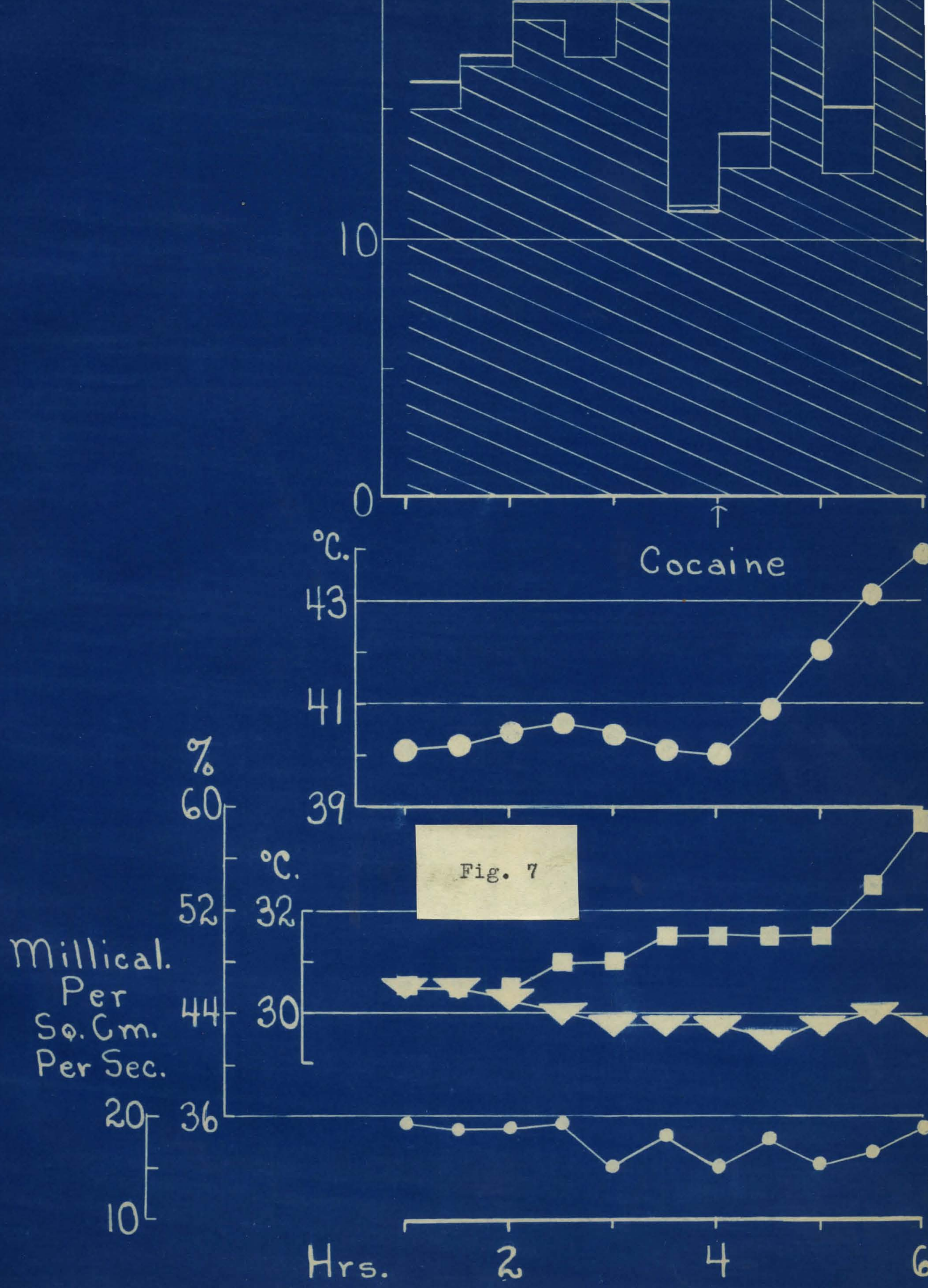

$>$
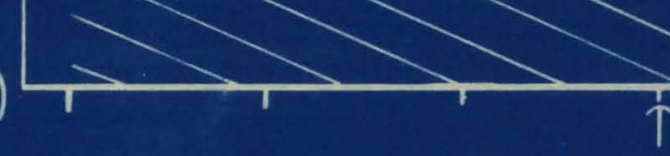
experiment, hourly periods were used and it is entirely possible that all the increase in water loss occurred during the second half hour rather than increasing immediately after the cocaine.) In experiments 3 and 5 , the total insensible loss was decreased below the normal average value while in Exp. 4 there was an increase of $79 \%$ which however, amounts to only 0.44 grams for that particular rabbit. From the above results it is evident that the characteristic water loss from the blood can by no means be attributed to increased water loss from the body.

After the first half hour following cocaine there was a 'marked increase in insensible loss in all experiments except Exp. 1. The value of determining the $\mathrm{CO}_{2}-\mathrm{O}_{2}$ difference in a study of the loss of water by vaporization is clearly brought out. In some periods in which the respiratory quotient fell below 0.727 , at which point the $\mathrm{CO}_{2}-\mathrm{O}_{2} 0$, the change fin weight due to the exchange of these gases is a positive rather than a negative quantity. Thus the loss due to vaporization was here greater than - the total net loss.

In connection with this marked increase in insensible loss after the first half hour following cocaine a definite relation was found between rectal temperature and rate of water loss. In Fig. 8 the average rectal temperature is plotted against the 
Legend to Figure 8.

Abscissae: Rectal temperature ${ }^{\circ} \mathrm{C}$ :

Oridinates: Water vaporized from skin and respiratory tract

in grams per square meter per hour.

Small white dots from Exp. 1.

Gircles from Exp. 2.

Crosses from Exp. 3 .

Squares from $\operatorname{Exp} .4$.

Triangles from Exp. 5.

Heavy line represents a smoothed curve of these points. 


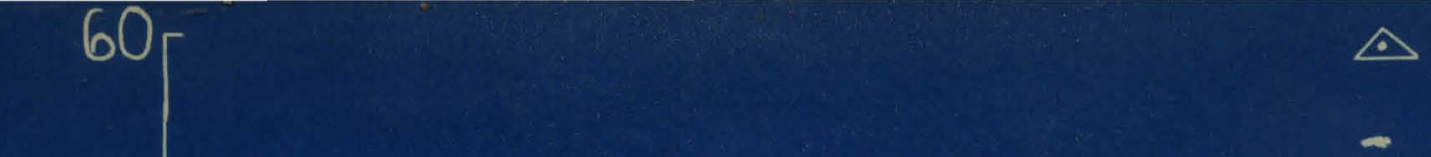

Gms. $/ S_{\varphi} \cdot m_{0} / H_{r}$

$50-$

Fig. 8

$30-$

40
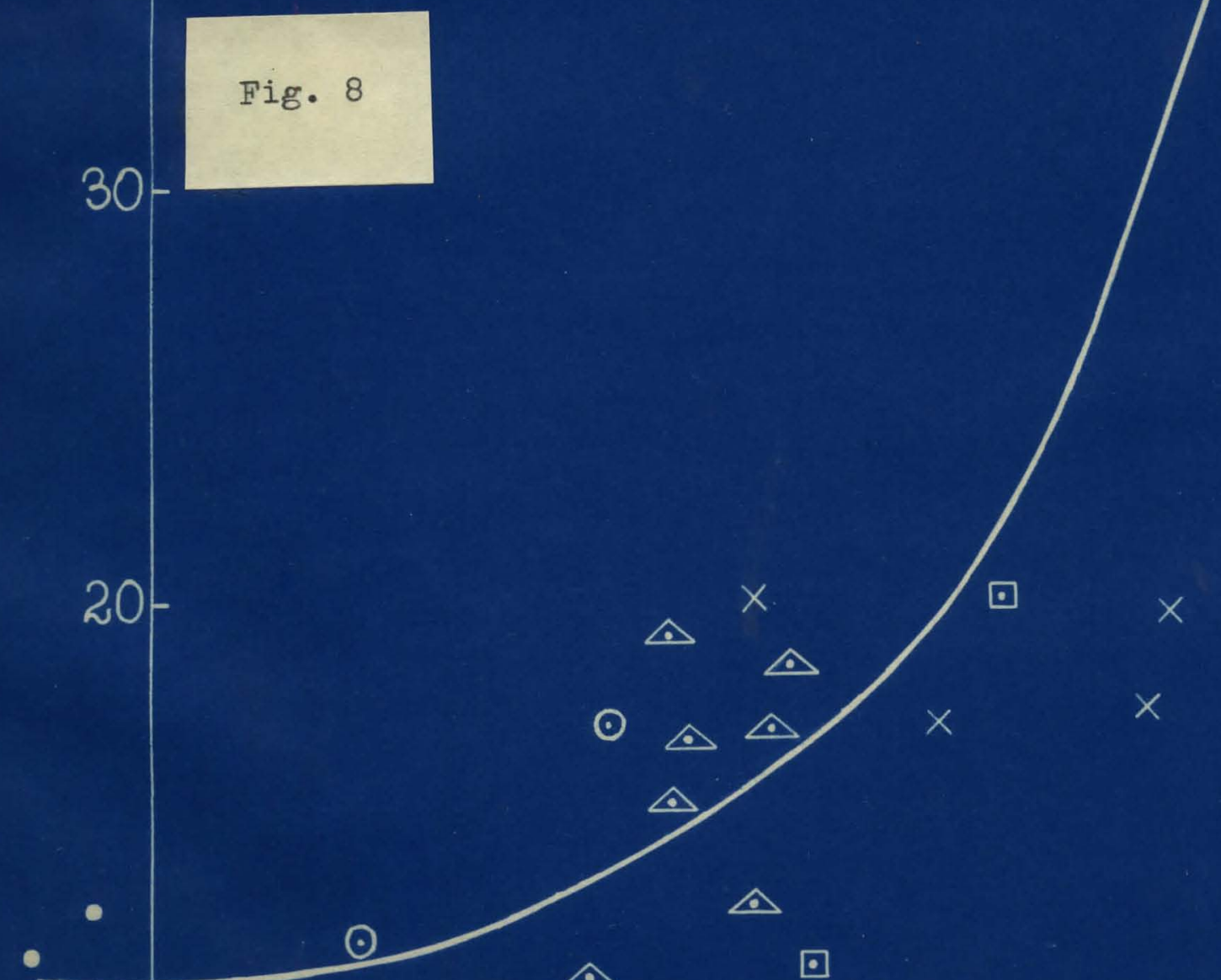

ㅁ

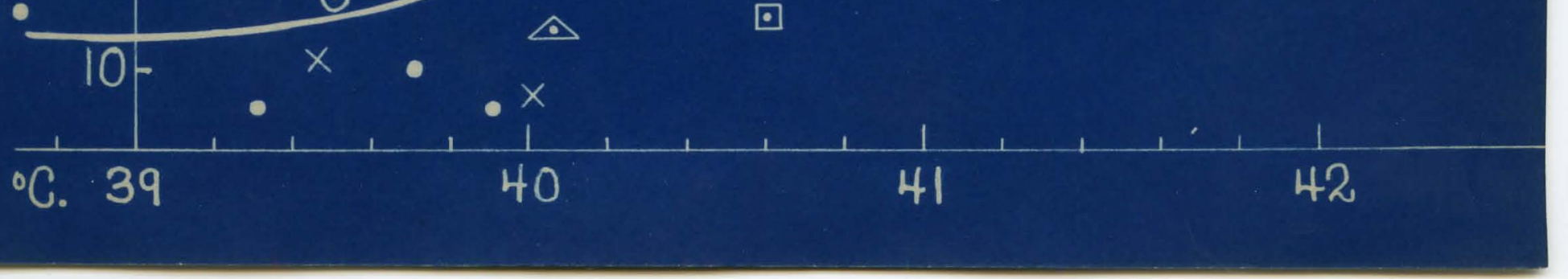


total water loss for each period in all our experiments in which both rectal temperature and water loss curves were on the rise. This chart shows a marked increase in the rate of vaporization at a rectal temperature in the neightorhood of $41.0^{\circ} \mathrm{C}$. This resembles the change in the weight loss curve in man when sweating begins. The rabbit, although not possessing sweat glands, seems able to increase his water loss from the skin considerably, upon attaining a certain eritical body temperature, viz. about $41^{\circ} \mathrm{C}$

Both total heat production and expired air volume were always increased following pyretic doses of cocaine (Expts. 2 - 5) The average total heat production in the animals before cocaine injection was 29.31 calories per square meter per hour. The maximum deviation of this average from the average for each experiment is only 2.47 calories per square meter per hour. This average total heat production in normal rabbits is also in close agreement with the value obtained by Kayser (23). During the first half hour following cocaine there was an average increase of $39.1 \%$ in the total heat production. The relation of this to the febrile process is discussed below. After the first half hour there was not much change in the heat production. B. Excretion of Water.

In studying the rate of water excretion, other than that vaporized, only two channels need be considered. They are the kidney and the alimentary tract. 
There is no evidence in the literature to indicate that cocaine acts as a diuretic under any conditions. The work of waestro (24) showg that the urinary output is decreased by cocaine. For example in one of his experiments the urinary output decreased from 160 to $85 \mathrm{cc}$. during the first day after giving 0.5 gram.

Observations upon the fevered animels in the experiments given in this paper revealed no evidence of diuresis, diarrhea or salivation, sufficient to account for a significant amount of water.

While it is still entirely possible that enough water could be excreted through these channels to easily account for the blood concentration there seems to be no reason to believe that such a thing does happen. Existing evidence seems to indicate the opposite effect, that is, a decrease in the rate of excretion.

\section{DISCUSSION.}

It seems evident from the results of these experiments that pyretic doses of cocaine have no appreciable effect upon the rate of vaporization or excretion of water during the first half hour following their administration. Certainly there is not a sufficient increase to account for a significant quantity of the water lost from the blood during this half hour. This result accords with the idea that increased heat production causes a rise in body temperature because elimination of heat fails to keep pace. 
In considering the increased water loss occurring after this first half hour period, simultaneously with an increase in the expired air volume the possibility that it may be due to an increase in the amount of water carried from the respiratory tract presents itself. No attempt was made in these experiments to separate the water vaporized from the respiratory tract from that vaporized from the skin. In two experiments, however, colculation was made of the possible maximum increase in water loss from the Iungs upon the assumption that the expired air was saturated with water vapor at body temperature. The following results were obtained. In Exp. 4, 32.3 grams more water per square meter per hour were lost than normally during the third period following cocaine. Calculation shows that only $8.7 \%$ of this increase was due to increased vaporization from the respiratory tract. In Exp. 5 there is an increase of 43.3 grams per square meter per hour in total water loss above the average normal during the second period following cocaine. Similar calculation shows that $22 \%$ of this increase was due to increased vaporization from the respiratory tract. The above examples show therefore that the increase in volume of expired air plays little part in the increased water loss even if the assumption that the expired air is completely saturated is correct. Granting that expired air is normally completely saturated it is evident that the air collected under 
the conditions of these experiments is not completely saturated due to the extra "dead space" in the mask and T-tube. The inspired air is probably a little more saturated than the relative humidity figures show, due to the contact of the in-going air with the moist valves and T-tube. Both of these factors or either of them separately would tend to lower the percentage of water loss attributable to the expired air. It is evident then that most of the increase in water loss must be attributed to increased vaporization from the skin.

Is this sharp rise after the first half hour following cocaine a physiological process related to the outbreak of sweat. in man? The only answer to this question available at present is that there seems to be a sudden outburst of water at a "critical" body temperature. Evidence given in this paper shows that this "critical" body temperature is in the neighborhood of $41.0^{\circ} \mathrm{C}$.

The increase in total heat production must at the onset be attributed to the excitatory effect of the alkaloid upon the central nervous system. The expired air volume and the respiratory quatient are evidently augmented by the same factors as in ordinary muscular exercise. As the body temperature rises all these phenomena are increased further by warming the cells, with a higher metabolic rate, heat polypnea and blowing off of $\mathrm{CO}_{2}$ respectively. (See especially Exp. 5.) 



\section{General Significance of Results.}

One of the most marked reactions to pyretic doses of cocaine is at first the increase in motor activity. But why does the temperature rise during cocaine hyperactivity and not during ordinary muscular activity? The answer is found in the study of the water shift.

In making a rough calculation of the rearrangement. of the water balance brought about by cocaine the following factis are brought out by the results of the experiments described in this paper. The blood specific gravity is increases by about three units in the third place. For example, a concentration from 1.0470 to 1.0500 is typical. Calculation shows that this change in specific gravity can be brought about by the loss of approximately $6 \mathrm{cc}$. of water from the blood. The amount of water neessary to cause a decrease in Iiver solids from $28 \%$ to $26 \%$ is about $8 \mathrm{cc}$. for the average sixed rabbit uged in these experiments, more than accounting for water loss from the blood.* Since no further evidence of significant deposttion or elimination of this water has been found it may be concluded that the water shift following cocaine takes place essentially between blood and Iiver.

$$
\text { What then is the mechanism of cocaine fever? There is }
$$
at the onset an increase in total heat production. The essential fact, however, is the fnability of the animal to increase the heat elimination. 
The following chain of events would account for the onset of the fever.

1. An increase in heat production coincident with a shift of water to the liver, a recognized seat of morphologic and metabolic change after cocaine. This results in concentration of the blood.

2. The blood concentration together with the wellknown peripheral vaso-constriction would markedly reduce the blood flow through the peripheral circulation. Inability to increase the heat elimination by vaporization would follow, as well as decreased loss from radiation, conduction and convection. 3. The positive heat balance, with rising temperature, would continue so long as the animal is unable to lose heat as fast as it is being produced. 
$\mathrm{S} U \mathrm{M} \mathbf{M} \mathrm{A} \mathrm{Y}$. 
S U H H $\mathrm{H}$ Y.

1. Following pyretic doses of cocaine in the rabbit (20 - 40 mgns per kilo) there was a definite loss of fluid from the blood, an increase in total heat production and a rise in rectal temperature.

2. Contrary to expectations there was no change in the water content of the brain. Studies of skin, muscle and kidney showed no significant change in their water content.

3. During the rise in rectal temperature there was an increase in the water content of the liver. The average decrease in liver solids amounted to $7.50 \%$. Calculation showed that this would account for an addition of about $8 \mathrm{cc}$. of water to the liver while an average figure for the amount of water lost from the blood was about $6 \mathrm{cc}$. Evidently the blood concentration was accounted for by a shift of water from the blood to the liver.

4. No evidence of deposition of fluid in the pleural, pericardial or peritoneal cavities was found.

5. There was no significant change in the rate of vaporization of water from the body during the first half hour after cocaine while this was the period in which the blood concentration occured and the sharpest rise in the fever curve was observed. 
6. A marked increase in rate of vaparization of water occured at a rectal temperature of about $41^{\circ} \mathrm{C}$.

7. The total heat production rose about $40 \%$ above the normal during the first half hour following cocaine. Evidentily heat eIimination by vaporization is not increased and probably there was very little if any increase in heat elimination in any way during this period. The positive heat balance results in the characteristic fever. 
C ONCLUSIONS.

$\because$ 
1. The water lost from the blood stream is shifted chiefly if not entirely to the Iiver.

2. This shift of water causes a concentration of the blood. This concentration associated with marked vasoconstriction results in an inability of the animal to increase the rate of heat elimination by vaporization and prabably in other ways, while the heat production is simultaneously increased. These phenomena account well for the positiwe heat balance, giving the characteristic rise in body temperature.

3. The inability to increase heat elimination is the essential process in the production of fever rather than the increased heat production. 


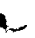

B I B I I G R A P H Y. 


\section{B I B L I O G R A P EY.}

1. Reichert, Edward T.: Cocaine as a Thermogenic: Its Modes of Action. Philadelphia Hed. Jour., Aug. 2, 1902.

2. Barbour, H.G. and Hoise, H.D.: The Hechanism of Cocaine Fever. Jour. Pharm. Exper. Therap., 192Z, XIX, 270.

3. Sarbour, H.G.: Heat Regulation and Water Exchange. XI. Blood and Plasme Changes in Cocaine and B. Coli Fevers and Aspirin Antipyresis. Jour. Pharm. Exper. Therap., 1926, XXIX, $427-440$.

4. Barbour, H.G., Russe11, B.E., Flowers, S.H., Dunham, E.S., and Hunter, L.G.: The Significant Redistribution of Water Between Internal and Surface Tissues and the Blood at the Height of Morphine Withdrawal. Am. J. Physiol., XC, 273.

5. Flowers, S.H., Dunham, E.S., and Barbour, H.G.: Addiction Edema and Withdrawal Edema in Morphinized Rats. Proc. Soc. Exper. Biol. and Med., 1929, XXVI, 572-574.

6. Ellerbrook, G.E., Dunham, E.S., and Barbour, H.G.: Effects of Diuretic Doses of Pitressin upon the Distribution of Water in the Brain and other Tissues, Jour. Fharm. Exper. Therap., (Proceedings) 1930 In press.

7. Mequarrie, Irvine: Epilepsy in Children. The Relationship of Water Balance to the Occurrence of Seizures. Am.J. Diseases Children. 1929, XXXVIII, 451-467.

8. Rowntree, Leonard G.: The Effects on Mammals of the Administration of Excessive Quantities of Water. Jour. Pharm. Exper. Therap., 1926, XXIX, 135-159.

9. Ellis, Mo.iu.: Guanidine Studies III. Water Content of Certain Tissues During Acute Guanidine and Parathyroprivia Tetanies. BioChem. Jour. 1928, XXII, 937.

10. Barbour, H.G. and Hamilton, W.F.: The Falling Drop Method for Determining Specific Gravity. Jour. Biol. Chem. 1926, IXIX, 625-640.

11. Barbour, H.G. and Hamilton, W.F.: The Falling Drop Hethod for Determining Specific Gravity. Some Glinical Applications. J.A.W.A., 1927 IXXXVIII, 91-94. 
11a. Lamson, Paul D.: The Role of the Liver in Acute Polycythaemia: A Mechanism for the Regulation of the Red Corpuscle Content of the Blood. Jour. Pharm. Exper. Therap., 19I5, VII, 181.

12. Koch, W. and Koch, MaA.: Chemical Differentiation of the' Brain. Jour. Biol. Chem., XV, 423.

13. Haldi, John, Larkin, Julitta and Wright, Pauline:

Weight Rolations in the Rabbit's Brain.

Am. J. Physiol., 1929, IXXXVIII, 107-111.

14. Lamson, Paul D., and Roca, John:

The Liver as a Blood Concentrating Organ.

Jour. Pharm. Exper. Therap., 1921, XVII, 481-497.

15. Eggleston, Cary and Hatcher, Robert A.: A Further Contribution to the Pharmacology of the Local

Anesthetics. Jour. Pharm. Exper. Therap., 1919, XIII, $433-487$.

16. Ehrlich, P.: Deutsche med. Wochenschr. 1890, 717

(cited by Heffter: Handb. d. Exp. Pharm. II (1)

Berlin, 1920).

17. Wallace, G.B. and Diamond, J.S.:

The Effect of Cocaine on the Liver.

(Personal communication.)

18. Gilbert, A. and Carnot, P.:

Sur une lesion exclusive des cellules Endotheliales du foil par la cocaino.

Compt. Rend. Soc. de Biol., 1902, LIV, 1383-1386.

19. Isenschmid: Med. KIin., 1918, XIV, 1128.

(cited by N.W. Johnston and L.H.Nerburgh. J.Clin. Invest., 1930, VIII, 149.)

20. Pearce, R.G.: Physiology and Biochemistry in wodern Medicine. Macleod. Sixth Ed., C.V.Mosly Co., St.Louis, 1930. Page 782.

21. Henderson, Yande11: Applications of Gas Analysis. IV. The Haldane Gas Analyzer. Jour. Biol. Chem.,1918, XXXIII, 31-38. 
2la. Henderson, Yandell: Applications of Gas Analysis. VI The Respiratory Exchange and Indirect Calorimetry, 1918, XXXIII, $47-53$.

22. Lusk, Graham: Science of lutrition. W.B.Saunders Co., Philadelphia, 1928, 4th Ed. Page 122.

23. Kayser, C.: Contribution a l'etude du mecanisme nerveux de la regulation thermique. Annales de Physiol et de Physico- chimie. $1929, \mathrm{~V}, 1-113$.

24. Maestro, L.: Le Modificazioni del Potere Riduttore delle Orine Nell'Avvelenamento Sperimentale per Cocaina Lo Sperimentale 1904, LVIII, 599. 